OPEN ACCESS

Edited by:

Renee Marije Van Der Sluis, Aarhus Institute of Advanced

Studies, Denmark

Reviewed by:

Marta Massanella,

IrsiCaixa, Spain

Michael Roche,

Peter Doherty Institute for Infection and Immunity, Australia

*Correspondence: William A. Paxton w.a.paxton@liverpool.ac.uk Georgios Pollakis g.pollakis@liverpool.ac.uk

Specialty section:

This article was submitted to

Virus and Host,

a section of the journal

Frontiers in Cellular and Infection Microbiology

Received: 05 February 2020 Accepted: 13 March 2020 Published: 07 April 2020

Citation:

Thomas J, Ruggiero A, Paxton WA and Pollakis G (2020) Measuring the Success of HIV-1 Cure Strategies. Front. Cell. Infect. Microbiol. 10:134. doi: 10.3389/fcimb.2020.00134

\section{Measuring the Success of HIV-1 Cure Strategies}

\author{
Jordan Thomas ${ }^{1}$, Alessandra Ruggiero ${ }^{1,2}$, William A. Paxton ${ }^{1 *}$ and Georgios Pollakis ${ }^{1 *}$ \\ ${ }^{1}$ Department of Clinical Infection, Microbiology and Immunology, Institute of Infection and Global Health, University of \\ Liverpool, Liverpool, United Kingdom, ${ }^{2}$ Immune and Infectious Disease Division, Academic Department of Pediatrics (DPUO), \\ Bambino Gesù Children's Hospital, Rome, Italy
}

HIV-1 eradication strategies aim to achieve viral remission in the absence of antiretroviral therapy (ART). The development of an HIV-1 cure remains challenging due to the latent reservoir (LR): long-lived CD4 T cells that harbor transcriptionally silent HIV-1 provirus. The LR is stable despite years of suppressive ART and is the source of rebound viremia following therapy interruption. Cure strategies such as "shock and kill" aim to eliminate or reduce the LR by reversing latency, exposing the infected cells to clearance via the immune response or the viral cytopathic effect. Alternative strategies include therapeutic vaccination, which aims to prime the immune response to facilitate control of the virus in the absence of ART. Despite promising advances, these strategies have been unable to significantly reduce the LR or increase the time to viral rebound but have provided invaluable insight in the field of HIV-1 eradication. The development and assessment of an $\mathrm{HIV}-1$ cure requires robust assays that can measure the LR with sufficient sensitivity to detect changes that may occur following treatment. The viral outgrowth assay (VOA) is considered the gold standard method for LR quantification due to its ability to distinguish intact and defective provirus. However, the VOA is time consuming and resource intensive, therefore several alternative assays have been developed to bridge the gap between practicality and accuracy. Whilst a cure for HIV-1 infection remains elusive, recent advances in our understanding of the LR and methods for its eradication have offered renewed hope regarding achieving ART free viral remission.

\section{Keywords: HIV-1, persistence, latency, latent reservoir, DNA/RNA quantification}

\section{INTRODUCTION}

Infection with human immunodeficiency virus type-1 (HIV-1) requires life-long adherence to antiretroviral therapy (ART) due to the presence of latently infected cells that are central to viral persistence and rebound viremia following ART interruption (Chun et al., 1997, 1998, 1999; Finzi et al., 1997; Perelson et al., 1997; Wong et al., 1997; Davey et al., 1999; Rosenbloom et al., 2017). HIV-1 primarily infects activated CD4 T cells, where genomic RNA is reverse transcribed into DNA and stably integrated into the host genome. Integrated proviral DNA therein serves as the template for HIV-1 gene expression and genomic RNA production, driven by $\mathrm{T}$ cell activation induced transcription factors such as NF- $\mathrm{kB}$ (Liu et al., 1992; Kinoshita et al., 1998). The latent reservoir (LR) is established when a small subset of activated CD4 T cells, harboring proviral DNA, revert to a resting memory phenotype with reduced gene expression, rendering the cell non-permissive for HIV-1 production but providing a sanctuary to evade the immune response and ART 
(Hermankova et al., 2003; Siliciano and Greene, 2011). The LR is stable over long periods in therapy suppressed individuals; the result of infection in naturally long-lived memory CD4 T cells that are continually replenished by clonal expansion and homeostatic proliferation (Finzi et al., 1999; Siliciano et al., 2003; Bailey et al., 2006; Chomont et al., 2009; Maldarelli et al., 2014; Wagner et al., 2014; Cohn et al., 2015; Lorenzi et al., 2016; Simonetti et al., 2016; Hosmane et al., 2017). Latently infected cells therefore represent the principle barrier to an HIV1 cure and should be specifically targeted by novel treatment and eradication strategies.

To date, an effective cure for HIV-1 infection has been achieved twice via CCR $5 \Delta 32 / \Delta 32$ hematopoietic stem cell transplantation and in both cases latently infected cells were eliminated and replaced with HIV-1 resistant donor cells (Hutter et al., 2009; Gupta et al., 2019). Whilst this method is not feasible for widespread use, its repeated success proves the principle that HIV-1 cure strategies must either eliminate (sterilizing cure) or silence (functional cure) the LR. Proposed cure strategies such as "shock and kill" aim to eliminate the LR by utilizing latency reversing agents (LRAs) during ART mediated virus suppression to drive expression of HIV1 from latently infected cells, exposing those cells to viral cytopathic effects or immune clearance whilst limiting de novo infections (Deeks, 2012). An alternative and conceptually opposing method, "block and lock," aims to reinforce viral latency and therefore maintain the provirus in an inactivate state in the absence of ART (Mousseau et al., 2015; Méndez et al., 2018). Additionally, therapeutic vaccination based approaches aim to silence the LR by inducing strong HIV-1 specific $\mathrm{T}$ cell responses to aid immune control of the infection following ART cessation (Mylvaganam et al., 2015; Pantaleo and Levy, 2016).

Measuring the success of HIV-1 cure and vaccine strategies requires highly sensitive and accurate assays and there is currently no consensus as to the most appropriate method to utilize. Several technical challenges limit the ability to measure accurately the size of the LR, including the paucity of cells infected with replication competent provirus and the vast heterogeneity of the HIV-1 genome. Culture based assays such as the viral outgrowth assay (VOA) are routinely used to measure the LR but are labor and resource intensive and invariably underestimate the size of the replication competent reservoir (Ho et al., 2013; Bruner et al., 2015). Conversely, PCR based assays offer a more practical approach to proviral quantification but overestimate the size of the LR by indiscriminately measuring defective viral genomes that predominate the in vivo landscape (Ho et al., 2013).

Despite the success of ART in reducing HIV-1 associated mortality, the global burden of the disease necessitates the urgent development of a cure or vaccine and both understanding and accurately measuring the LR is crucial in the path toward HIV1 eradication. In this review, we will focus on the mechanisms that facilitate the establishment and maintenance of the HIV-1 LR, some of the prominent methods proposed to achieve a cure and the developments and challenges on the way to measuring their success.

\section{THE LATENT RESERVOIR}

\section{Establishing Latency}

The HIV-1 LR can be defined as the fraction of cells harboring transcriptionally silent proviral DNA that are capable of producing infectious virions following activation (Eisele and Siliciano, 2012). Resting memory CD4 $\mathrm{T}$ cells are the primary host of the LR but HIV-1 infection in these cells is inefficient due their low co-receptor expression and inherent restrictions to reverse transcription (Pierson et al., 2000; Baldauf et al., 2012). Nevertheless, there is evidence that HIV-1 can infect resting CD4 T cells directly or via cell-to-cell transmission, though infection in these cells is associated with slower replication kinetics (Swiggard et al., 2004, 2005; Agosto et al., 2007, 2018; Plesa et al., 2007; Vatakis et al., 2007; Lassen et al., 2012). Alternatively, latency is established when a subset of infected, activated CD4 $\mathrm{T}$ cells revert to a resting memory phenotype, effectively silencing viral gene expression whilst sustaining the proviral DNA long-term (Chun et al., 1995). The provirus is maintained in a quiescent state in these cells via host factors such as epigenetic suppression, depletion of transcription factors such as NF- $\kappa \mathrm{B}$ and transcriptional interference due to integration into expressed genes, reviewed in more detail (Cary et al., 2016).

Amongst the pool of viral genomes integrated into host cells, only a small fraction are replication competent and therefore capable of producing infectious $\mathrm{HIV}-1$ virions following $\mathrm{T}$ cell activation (Sanchez et al., 1997; Ho et al., 2013; Bruner et al., 2016; Imamichia et al., 2016). Instead, the majority of the reservoir exists as defective provirus, unable to support HIV-1 infection due to deletions, insertions and hypermutation introduced into the genome during reverse transcription (Ho et al., 2013; Bruner et al., 2016). Despite this, viral rebound from the LR following ART cessation is rapid, leading to detectable viremia within weeks of therapy interruption (Chun et al., 1999; Davey et al., 1999). Additionally, initiating ART early in infection is not sufficient to stop the formation of the LR, suggesting the LR is established and disseminated early (Chun et al., 1998; Whitney et al., 2014; Colby et al., 2018), even in vertically infected children that started ART soon after birth (Persaud et al., 2013; Ananworanich and Robb, 2014; Giacomet et al., 2014; Tagarro et al., 2018).

\section{Maintaining the Reservoir}

The half-life of the LR is estimated to be 3.6 years in patients with sustained viral suppression, meaning that eradication of the LR is not possible within a lifetime and adherence to ART must therefore be lifelong (Siliciano et al., 2003; Crooks et al., 2015). The natural longevity of memory T cells contributes to the persistence of the LR, however, its long-term stability indicates that this pool of cells is continually replenished notwithstanding effective ART. Two mechanisms have been proposed as drivers of LR maintenance: ongoing virus replication in anatomical compartments with sub-optimal drug concentrations and/or clonal expansion of latently infected cells (Sengupta and Siliciano, 2018). Ongoing replication of HIV-1 would lead to the accumulation of genetically diverse HIV-1 provirus, integrated into various positions of the host genome, therefore, 
researchers have monitored viral evolution and integration sites in ART suppressed patients to determine the mechanism of LR propagation. Separate studies have demonstrated a high proportion of genetically indistinct viral genomes, as well as identical integration sites recovered from different cells, indicating that these cells must arise from proliferation as appose to subsequent HIV-1 replication (Josefsson et al., 2013; Wagner et al., 2013, 2014; Maldarelli et al., 2014; von Stockenstrom et al., 2015; Wang Z. et al., 2018). Indeed, memory T cells are maintained by homeostatic proliferation in response to IL-7, and several studies have shown that this process drives LR persistence without inducing HIV-1 gene expression (Agosto et al., 2007; Chomont et al., 2009; Archin et al., 2012). These studies, however, do not demonstrate that the expanded viral clones are replication competent and therefore, their contribution to HIV-1 persistence is unclear. One study, in fact, revealed that of a population of 75 expanded clones, none of the proviral sequences were found to be replication competent (Cohn et al., 2015). To address this, researchers have utilized full-length sequencing approaches to demonstrate that within the replication competent proviral pool, $55-60 \%$ of viral genomes had identical sequences in different cells (Lorenzi et al., 2016; Hosmane et al., 2017). Further, a recent longitudinal analysis revealed that rebound viremia matched archival provirus that was present prior to ART initiation and during long term ART suppression (De Scheerder et al., 2019). Taken together, these studies indicate that cellular expansions play a key role in the maintenance of the replication competent viral reservoir in long-term therapy suppressed patients, providing a clear mechanism for HIV-1 persistence and a source of rebound viremia following ART cessation.

On the other hand, the contribution of low-level virus replication in anatomical compartments with sub-optimal drug concentrations, such as lymph nodes (LN), to LR maintenance is a topic of continued debate (Fletcher et al., 2014; Fukazawa et al., 2015; Lorenzo-Redondo et al., 2016; Nolan et al., 2017; Bozzi et al., 2019). Generally, most studies demonstrate little evidence of provirus evolution in ART suppressed patients, refuting the likelihood that ongoing replication is continually seeding the reservoir (Bailey et al., 2006; Chomont et al., 2009; Josefsson et al., 2013; Hiener et al., 2017; Lee et al., 2017; Van Zyl et al., 2017; Bozzi et al., 2019; De Scheerder et al., 2019). Additionally, ART intensification studies have been unable to reduce low-level viremia, suggesting that this phenomena is a result of stochastic activation of latently infected cells, rather than continued rounds of replication (Dinoso et al., 2009; McMahon et al., 2010; Anderson et al., 2011; Gandhi et al., 2012). Nevertheless, evidence from various studies has supported the hypothesis that ongoing replication takes place notwithstanding suppressive ART. Intensification of the integrase inhibitor raltegravir, for example, led to transient increases in 2-LTR circular DNA which, as products of failed integration events, suggests inhibition of new infections (Buzón et al., 2010; Hatano et al., 2013; Puertas et al., 2018). Further, evidence of virus evolution within the LN of therapy suppressed patients was also suggested as an indication of ongoing replication (Lorenzo-Redondo et al., 2016). However, two groups have reported that this is instead an artifact of rapidly decaying viral species associated with early antiretroviral treatment (Kearney et al., 2017; Rosenbloom et al., 2017).

\section{The Hosts of the Reservoir}

Critical to the elimination of HIV-1 is the elucidation of the specific anatomical and cellular reservoirs of HIV-1. Various differentiation states of CD4 T cells appear to play important roles in the establishment and maintenance of the LR as well as viral recrudescence following ART interruption (Buzon et al., 2014; Kulpa and Chomont, 2015; Banga et al., 2016; De Scheerder et al., 2019; Falcinelli et al., 2019). As discussed above, the LR is primarily hosted in memory CD4 T cells, specifically, central $\left(\mathrm{T}_{\mathrm{CM}}\right)$, transitional $\left(\mathrm{T}_{\mathrm{TM}}\right)$, effector memory $\left(\mathrm{T}_{\mathrm{EM}}\right)$, and memory stem $\left(\mathrm{T}_{\mathrm{SCM}}\right)$ cells, although the exact contribution of each cell type to the replication competent reservoir is still to be determined (Chomont et al., 2009; Buzon et al., 2014; Soriano-Sarabia et al., 2014; Banga et al., 2016, 2018; Kwon et al., 2020). Recently, CD32+ CD4 T cells have been proposed to be a major host of the LR, whereby selection of this cell population resulted in significant enrichment of inducible provirus (Descours et al., 2017; Darcis et al., 2020). Conflicting reports, however, have failed to replicate this finding and the contribution of CD32+ CD4 T cells to HIV-1 persistence and rebound remains controversial (Abdel-Mohsen et al., 2018; Badia et al., 2018; Bertagnolli et al., 2018; Martin et al., 2018; Osuna et al., 2018; Pérez et al., 2018). Nonetheless, the use of CD32 as a marker of latent infection is a topic of particular interest and may provide a mechanism by which the LR can be specifically targeted.

As well as categorizing cells based on their differentiation state, these cells can also be subdivided based on their functional properties. Accordingly, specific CD4 functional sub-sets, such as regulatory $\mathrm{T}$ cells $\left(\mathrm{T}_{\text {reg}}\right)$, Th17 cells and follicular $\mathrm{T}$ helper cells $\left(\mathrm{T}_{\mathrm{fh}}\right)$ are now being characterized in more detail to determine which cells are the primary contributor to HIV-1 latency. $\mathrm{T}_{\text {reg }}$ cells modulate the immune response through regulation of $\mathrm{T}$ cell proliferation and differentiation whilst Th17 cells are critical to maintaining mucosal immunity via secretion of IL-17 and the balance of these two cell subsets is therefore critical in providing effective immune function (Valverde-Villegas et al., 2015). Both $\mathrm{T}_{\text {reg }}$ and Th17 cells have been shown to harbor a high proportion of the LR in therapy suppressed patients and as such, may be an important target in HIV-1 cure efforts (Tran et al., 2008; Alvarez et al., 2013; Sun et al., 2015; Christensen-Quick et al., 2016; Caruso et al., 2019).

Due to the inherent difficulty of sampling from tissues, most LR studies are based on the analysis of peripheral blood. In recent years, more research has focused on studying anatomical reservoirs such as lymph nodes (LN) and gut associated lymphoid tissue (GALT), as these sites are enriched in activated CD4 T cells (Chun et al., 2008; Di Mascio et al., 2009; Yukl et al., 2010; Churchill et al., 2016). Follicular $T$ helper cells $\left(\mathrm{T}_{\mathrm{fh}}\right)$, resident within the B cell follicle of LN have recently been identified as a major host of the replication competent viral reservoir (Buzon et al., 2014; Banga et al., 2016, 2019). These studies demonstrate the importance of individual anatomical and cellular hosts of the LR to HIV-1 persistence and highlight that HIV-1 eradication 
studies will need to not only target these sites, but also efficiently and specifically measure the LR within these compartments.

In addition to lymphocytes, a number of other cells types such as macrophages and plasmacytoid dendritic cells (pDCs) are potential hosts of the LR, and despite being infected at a lower frequency, may play an important role in viral persistence (Centlivre et al., 2011). Studies suggest that macrophages infected with HIV-1 are resistant to cell mediated immune clearance as well as virus induced cell death and may therefore represent a significant hurdle to cure (Swingler et al., 2007; Clayton et al., 2018). Further, replication competent provirus has recently been recovered from macrophages in long-term ART suppressed patients, indicating that cure strategies targeting only lymphocytes may not be sufficient (Ganor et al., 2019). Infection of macrophages with HIV-1 can facilitate entry of virus into anatomical sanctuary sites such as the brain and central nervous system (CNS), therefore providing an additional barrier to HIV-1 eradication (Castellano et al., 2017; Wong et al., 2019).

\section{HIV-1 CURE STRATEGIES}

\section{Progress Toward a Cure}

The progress toward the development of a functional or sterilizing cure for HIV-1 has been significantly hindered by the presence of the LR. Currently, two people have been cured of HIV-1 infection, the so-called Berlin and London patients, who since receiving allogenic stem cell transplantations from CCR $5 \Delta 32 / \Delta 32$ donors, have consistently tested negative for viral rebound for over 10 and 2 years, respectively, without ART (Hutter et al., 2009; Gupta et al., 2019). In these cases, the infected cell pool was significantly depleted during pretransplant conditioning and replaced with donor cells that are resistant to infection with $\mathrm{R} 5$-tropic virus due a large deletion in the CCR5 co-receptor (Liu et al., 1996). Due to the relative paucity of CCR $5 \Delta 32 / \Delta 32$ donors and the unique circumstances predetermining these cases, this type of cure is not feasible for widespread use, it does however emphasize the basic principle of HIV-1 cure; silence or eradicate the HIV-1 LR.

\section{Shock and Kill}

One of the most prominent approaches to achieve HIV-1 cure is "shock and kill"; the use of latency reversing agents (LRAs) to induce viral gene expression and productive infection in latently infected cells, exposing those cells to immune clearance or the viral cytopathic effect with the aim of reducing the size of the LR and limiting viral rebound (Figure 1; Deeks, 2012). A major challenge in this approach is the ability to achieve broad and efficient latency reversal without eliciting toxic side effects or global immune activation. Early latency reversal studies that utilized interleukin-2 (IL-2) to induce HIV-1 activation produced a toxic "cytokine storm" response and did not sufficiently reduce the size of the LR when the dosage was lowered to safer levels (Prins et al., 1999; Lafeuillade et al., 2001). Instead, novel LRAs induce HIV-1 gene expression either by activating cellular transcription factors, such as NF- $\mathrm{kB}$, or by altering the chromatin structure of the integrated provirus. In their review, Abner and Jordan extensively list published LRAs and categorize them into six groups based on their mechanism of action as follows: histone post-translational modification modulators, non-histone chromatin modulators, NF- $\kappa \mathrm{B}$ stimulators, TLR agonists, extracellular stimulators, and a miscellaneous category of unique cellular mechanisms (Abner and Jordan, 2019).

Some of the prominent LRAs currently in use in ongoing clinical trials include histone deacetylate inhibitors (HDACi) and histone methyltransferases inhibitors (HMTi), which induce HIV-1 expression by reversing epigenetic silencing (Lehrman et al., 2005; Agosto et al., 2007; Archin et al., 2012, 2014a; Delagrèverie et al., 2016; Aid et al., 2018; Abner and Jordan, 2019). Alternatively, protein kinase C (PKC) agonists (Williams et al., 2004; Perez et al., 2010; Marsden et al., 2018) and CCR5 agonists (López-Huertas et al., 2017; Madrid-Elena et al., 2018) stimulate latent HIV-1 by activating NF- $\mathrm{kB}$. The use of toll like receptor (TLR) agonists as LRAs has also been explored, as they stimulate immune signaling pathways, leading to HIV1 expression (Thibault et al., 2009; Novis et al., 2013; AlvarezCarbonell et al., 2017). As an alternative to conventional LRAs, the use of a polyvalent HIV-1 vaccine has been proposed as a potential candidate to initiate latency reversal, based on the rationale that latently infected CD4 T cells express HIV-1 specific $\mathrm{T}$ cell receptors (TCR) and are therefore activated by HIV-1 antigen presentation (Pankrac et al., 2017). These molecules have so far resulted in modest viral activation in vivo, however, two recent studies have demonstrated potent and persistent latency reversal in mouse and SIV models in multiple tissues as well as peripheral blood: one utilized a LRA that activates the noncanonical NF-kB pathway (Nixon et al., 2020) and the other combined CD8 T cell depletion with IL-15 stimulation (McBrien et al., 2020). Evidence suggests that the capacity of different LRAs to activate HIV-1 gene expression is varied amongst different $\mathrm{CD} 4 \mathrm{~T}$ cell subsets due to the diversity of the mechanisms that drive viral latency across these subsets (Grau-Expósito et al., 2019; Pardons et al., 2019b). Combinations of LRAs could therefore conceivably elicit more global reactivation by acting on different mechanisms that enforce viral latency, and synergy between multiple combinations of LRAs has so far been identified in vitro (Darcis et al., 2015; Jiang et al., 2015; Albert et al., 2017; Zaikos et al., 2018; Abner and Jordan, 2019; McBrien et al., 2020; van der Sluis et al., 2020). Nevertheless, achieving global reactivation of HIV-1 from latently infected cells is only part of the challenge; these cells must also be efficiently killed, either by the viral cytopathic effect or by cytotoxic T lymphocyte (CTL) mediated immune clearance. Currently, studies that have achieved latency reversal in vivo have failed to reduce the LR or increase the time to viral rebound (Xing et al., 2011; Doyon et al., 2013; Archin et al., 2014a,b, 2017; Elliott et al., 2015), indicating a deficiency in the clearance of infected cells. This impairment of the "kill" response may be due, in part, to loss of HIV-1 specific CTL responses in long-term suppressed patients (Chomont et al., 2018) that may need to be restored in order to achieve sufficient clearance of infected cells (Shan et al., 2012). Importantly, LRAs that activate HIV-1 mRNA expression may not be sufficient to induce the production of viral proteins or infectious virions, and therefore the presentation of viral antigens to CTLs via major histocompatibility complex class 1 (MHC-1) 


\section{Shock and Kill}

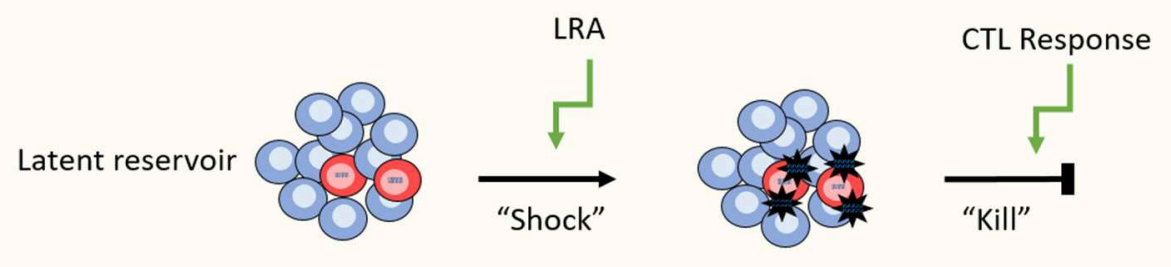

\section{ART blocks infection}

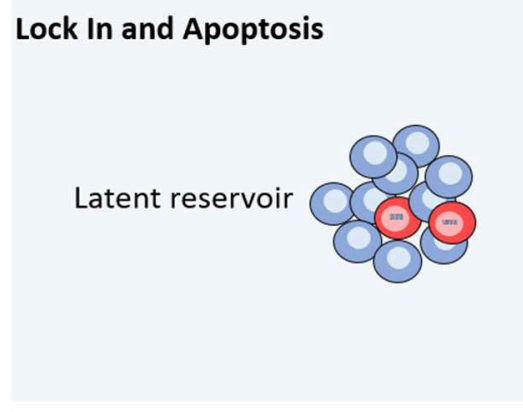

\section{Block and Lock}
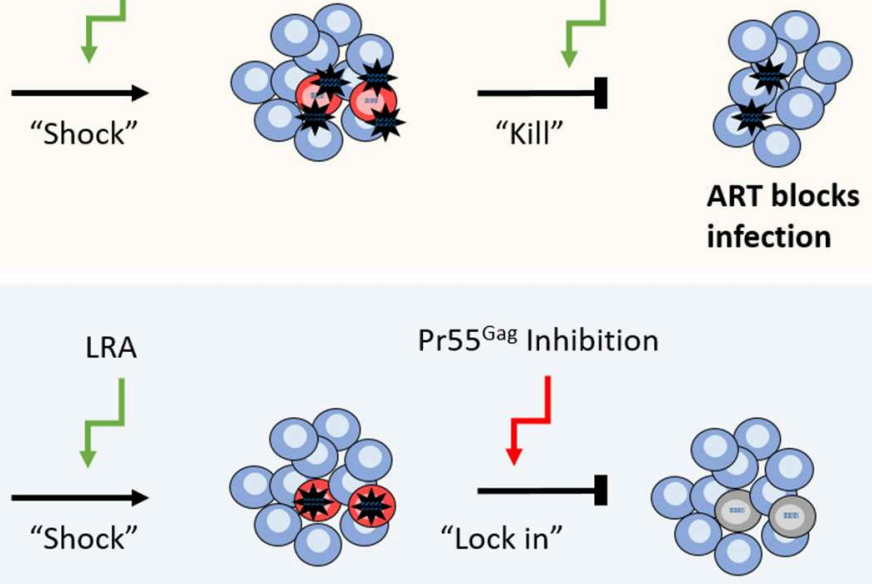

\section{Block and Lock}

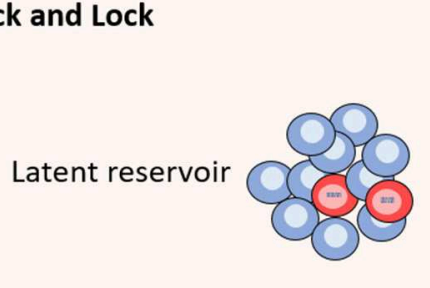

siRNA/

Tat inhibitor
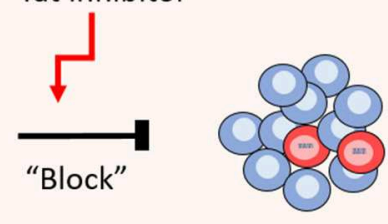

\section{Latency maintained}

FIGURE 1 | Different strategies for HIV-1 cure. From top to bottom. Shock and kill relies on reversal of latency using a range of different compounds including TLR agonists and HDACis, followed by CTL mediated cell clearance, whilst ART blocks new infections caused by virus release. Lock in and apoptosis utilizes latency reversal agents, as well as a Pr55Gag inhibitor to block virus budding from the cell. The build-up of viral RNA and proteins leads to apoptosis of the infected cell. Block and lock approaches aim to reinforce latency mechanisms by using siRNAs or Tat inhibitors to disrupt cellular epigenetic regulators or viral replication, respectively (red cells represent HIV-1 latently infected cells).

may be limited (Clutton and Jones, 2018; Grau-Expósito et al., 2019) Additionally, treatment with LRAs may specifically inhibit the clearance of infected cells, for example, HDACis have been shown to impair CTL function and the LRA, disulfiram, may induce an anti-apoptotic state that promotes cell survival despite productive viral infection (Jones et al., 2014; Knights, 2017). Interestingly, the recent finding that CD8 T depletion could significantly enhance latency reversal indicates that CD8 T cells may block HIV-1 reactivation by LRAs (McBrien et al., 2020).

These findings emphasize the need for a more specific and potent "kill" function, such as LRAs that enhance the clearance of infected cells or combinations of treatment strategies to aid CTL function. To this end, TLR agonists offer promise due to their ability to induce a broad anti-viral response, simultaneously activating virus production and priming immune clearance of HIV-1 infected cells (Borducchi et al., 2016; Tsai et al., 2017; Lim et al., 2018; Macedo et al., 2018). To circumvent the need for CTL mediated cell clearance altogether, an alternative approach is to block the release of virions and induce apoptosis of the infected cell (Tateishi et al., 2017). In this method, a novel compound is used to inhibit HIV-1 Pr55 ${ }^{\mathrm{Gag}}$, blocking virus budding and leading to a build-up of viral products and subsequent apoptosis of the infected cell (Figure 1; Tateishi et al., 2017).

\section{Block and Lock}

Recently, a novel cure strategy has been proposed that, rather than inducing latency reversal, aims to reinforce latency to prevent viral rebound following ART interruption (Figure 1; Mousseau et al., 2015; Méndez et al., 2018). The so called "block and lock" approach utilizes small interfering RNAs (siRNAs) to induce transcriptional gene silencing (TGS) by disrupting the regulation of chromatin structure, thereby preserving the epigenetic mechanisms that maintain HIV-1 latency (Suzuki et al., 2008; Ahlenstiel et al., 2015; Méndez et al., 2018). 
Alternatively, latency may be enforced by the targeted inhibition of the HIV-1 positive regulator, Tat, to lock the viral replication cycle at transcription (Mousseau et al., 2015). Whilst these approaches offer a conceptual alternative cure mechanism to "shock and kill," their development is still in preliminary stages and is yet to be tested in human trials.

\section{Gene Editing}

The rise to prominence of gene editing tools such as CRISPRCas9 and zinc-finger nucleases (ZFN) has led to increased hope of a HIV-1 cure by targeting various host or viral genes to induce host resistance, enforce viral latency or silence integrated provirus. Gene editing approaches have the advantage of highly specific gene targeting, so unlike LRAs, can produce the desired outcome without global physiological impact. Nevertheless, offtarget effects have been observed in a number of studies and may affect the safety of these methods (Kimberland et al., 2018). So far, the potential of ZFN targeted editing of host CCR5, to induce partial genetic resistance to $\mathrm{HIV}-1$, has been tested in a clinical trial (Tebas et al., 2014). Most research, however, has focused on the use of CRISPR-Cas9 for its relatively simple approach and number of studies have demonstrated its use in CCR5 or CXCR4 gene editing to induce host cell resistance to HIV-1 (Wang et al., 2014, 2017; Xu et al., 2017). This approach may also be used to specifically knockout or attenuate the HIV1 provirus, for example, by targeting the LTR to disrupt viral gene expression or excise the integrated genome (Ebina et al., 2013; Hu et al., 2014; Kaminski et al., 2016; Lebbink et al., 2017; Yin et al., 2017; Bella et al., 2018; Wang Q. et al., 2018). Alternatively, various positions of the latent provirus could be targeted by CRISPR-Cas9 to induce multiple non-homologous end joining (NHEJ) associated indels that deactivate the virus through frame shift mutation (Liao et al., 2015; Ueda et al., 2016; Wang et al., 2016; Ophinni et al., 2018). Additionally, recent work has shown that, in combination with a novel drug delivery system, CRISPR-Cas9 directed editing of proviral DNA could effectively eliminate HIV-1 infection in mouse models (Dash et al., 2019). This technology could feasibly be used to target myriad steps in the viral replication cycle, however, its major limitation is its delivery, requiring viral vectors or lipid compounds, as reviewed (Xiao et al., 2019). To achieve clinically significant effects, the majority, if not all of the LR will need to be affected, which is a major challenge considering the array of anatomical compartments which host a significant proportion of latently infected cells.

\section{Therapeutic Vaccination}

Rebound viremia from latently infected cells is detectable within weeks of ART interruption, though the exact cellular and anatomical source of this rebound varies between patients (De Scheerder et al., 2019). Therefore, rather than targeting this elusive source, therapeutic vaccination aims to eliminate or significantly diminish rebound viremia by priming the host immune response to HIV-1, thereby achieving a "functional cure." In therapeutic vaccine trials, the vaccine regimen is administered during sustained ART mediated viral suppression, followed by a period of ART interruption, during which vaccine efficacy can be assessed by measuring time to viral rebound, size of the LR and the profile of the host immune response.

Therapeutic vaccines may aim to elicit narrow CTL responses to specific HIV-1 proteins, such as Gag, though the success of these approaches may be impeded by the re-emergence of CTL escape mutants that were established during primary infection (Schooley et al., 2010; Pollard et al., 2014; Deng et al., 2015). Alternatively, vaccines designed to generate a broader anti-HIV1 immune response may be more effective. To this end, several studies have used a dendritic cell (DC) based vaccine, in which autologous DCs are pulsed with inactivated HIV-1, or transfected to produce viral proteins, with the aim of generating DCs that can efficiently stimulate T cell responses (García et al., 2011; Gandhi et al., 2016; Gay et al., 2017b). Further, a vaccine that expresses multiple HIV-1 proteins may be used to induce a multivalent immune response, and previous studies combining such vaccines with IL-2 to boost $\mathrm{T}$ cell survival have demonstrated moderate success, with increased time to viral rebound associated with HIV-1 specific T cell responses in vaccinated participants (Lévy et al., 2005, 2006). Of note, a recent report has demonstrated continual decreases in the proviral reservoir as well as recovery of immune function following Tat based immunization, signifying that therapeutic vaccination can improve the immune response to HIV-1 (Sgadari et al., 2019).

Despite the promise of vaccine-based approaches, no study has yet induced sustained viral remission in vaccinated patients and in their recent analysis, Davenport et al. suggest that, even with highly efficacious vaccines that block $80 \%$ of viral reactivations, rebound viremia would likely emerge within 5 weeks following ART interruption (Davenport et al., 2019). This suggests that therapeutic vaccination alone may not be sufficient to cure HIV-1 infection and that instead, combinations of cure strategies may be more effective. For example, considering that "shock and kill" strategies have so far failed to achieve meaningful reduction in the $L R$, combining these strategies with therapeutic vaccination may increase the efficacy of each treatment. Indeed, this principle was tested in a clinical trial where Gag based vaccination was followed by HDCAi latency reversal and though this study was able to significantly reduce the LR, rebound viremia was measured within 2 weeks (Leth et al., 2016; Tapia et al., 2017).

\section{Novel Cure Strategies}

Several novel approaches to induce sustained viral remission in treated patients have been proposed. One such method utilizes the relatively new discovery that exhausted CD4 T cells expressing immune checkpoint (IC) makers such as PD1 and CTLA-4, are a major reservoir of replication competent provirus (Banga et al., 2016; Fromentin et al., 2016; Castellano et al., 2017; McGary et al., 2017). IC markers are inhibitory receptors expressed by $\mathrm{T}$ cells in response to chronic viral infection to attenuate their effector function and limit tissue damage associated with long term immune activation (Boyer and Palmer, 2018). Cells expressing these markers, that are enriched in latent provirus, could therefore be specifically targeted for drug delivery or clearance using PD1, CTLA-4, or PD-L1 antibodies (Pantaleo and Levy, 2016; Gay et al., 2017a; Boyer and Palmer, 2018). To 
this end, several studies have demonstrated that IC blockade can inhibit the establishment of latency in vitro and aid latency reversal in vivo, revealing its potential as an HIV-1 therapeutic (McManamy et al., 2014; Gay et al., 2017a; Evans et al., 2018; Fromentin et al., 2019; van der Sluis et al., 2020).

Alternatively, following the success of chimeric antigen receptor $\mathrm{T}$ cells (CAR-T) in cancer therapy, their potential to treat HIV-1 is the subject of ongoing research. CAR-T cells are autologous $\mathrm{T}$ cells genetically engineered to express disease specific antibodies linked to an intracellular $\mathrm{T}$ cell receptor domain; therefore, when re-administered to the patient can direct the CTL response to cells expressing the disease epitope (Wagner, 2018). As such, this technology could be used to direct CTL mediated clearance of HIV-1 infected cells, aiding control of the virus in the absence of therapy. Currently, several studies using anti-HIV-1 CAR-T cells have demonstrated virus-clearing function in vitro (Sahu et al., 2013; Liu et al., 2015; Ali et al., 2016; Hale et al., 2017; Sung et al., 2018). More recently, a multispecific CAR-T cell demonstrated potent clearance of HIV-1 infected cells in a humanized mouse model (Anthony-Gonda et al., 2019). The use of CAR-T cells is therefore an exciting new prospect in HIV-1 therapeutics and may work synergistically with LRAs to add more killing power into the "shock and kill" approach.

As discussed earlier, myeloid cells such as macrophages are known to support virus replication and may represent an additional barrier to HIV-1 cure. The use of "shock and kill" may not be effective against these cellular reservoir as they are refractory to CTL mediated immune clearance and the viral cytopathic effect (Swingler et al., 2007; Clayton et al., 2018). To address this, researchers have demonstrated differential expression of an anti-apoptotic, long non-coding RNA (lncRNA) that promotes survival of HIV-1 infected macrophages (Boliar et al., 2019). This study also showed that inhibition of this lncRNA with small interfering RNAs (siRNAs) could induce apoptosis in HIV-1 infected macrophages, indicating the potential of targeting lncRNAs as a novel therapeutic approach to aid the clearance of the LR in all cell types (Boliar et al., 2019).

\section{ASSAYS TO MEASURE THE SUCCESS OF HIV-1 CURE \\ Viral Outgrowth Assay}

Assessing the efficacy of HIV-1 cure and vaccine trials requires assays that reproducibly measure different virological markers to estimate the size of the LR with limited error. This is inherently challenging because of the relatively low abundance of latently infected cells and the heterogeneity of the HIV1 genome, though several assays have been developed to this end (Table 1). Additionally, very few proviruses can generate infectious virions following activation and it is difficult to quantify specifically the replication competent reservoir. The standard assay used to measure intact provirus is the functional viral outgrowth assay (VOA) (Figure 2; Finzi et al., 1997, 1999; Siliciano and Siliciano, 2005). In this assay, limiting dilutions of CD4 $\mathrm{T}$ cells are stimulated to reverse latency and drive HIV-1 expression from integrated provirus. Activation of CD4 $\mathrm{T}$ cells is most commonly achieved via the addition of phytohemagglutinin (PHA) and CD8 T cell depleted PBMCs or by incubation with anti-CD28/CD3 antibodies (Wong et al., 1997; Finzi et al., 1999; Siliciano and Siliciano, 2005; Laird et al., 2013; Bruner et al., 2015). Following activation, viral outgrowth is supported by incubation with CD4 T cells from HIV-1 negative donors for 2-3 weeks and measured via the detection of p24 capsid antigen ELISA. Cell positive for exponential viral replication are quantified and the frequency of cells latently infected with intact provirus is determined based on Poisson distribution and expressed as infectious units per million (IUPM) cells (Siliciano and Siliciano, 2005; Rosenbloom et al., 2015).

The original VOA provides high specificity for intact provirus but is limited by the large sample volume required, high resource cost and is susceptible to donor variation due to virus propagation in primary CD4 T cells (Bruner et al., 2015; Massanella and Richman, 2016). Several improvements of the VOA have attempted to overcome these limitations, including the use of continuous cell lines to improve reproducibility (Laird et al., 2013; Fun et al., 2017; Badia et al., 2018; Massanella et al., 2018) the use of RT PCR to detect HIV-1 RNA reducing time to read out (Laird et al., 2013) or utilizing improved p24 ELISA to increase sensitivity (Passaes et al., 2017). Recently, a novel improvement of the VOA has been described in which CD4 T cells are differentiated into effector cells to promote expression of HIV-1, enhancing cell activation and thereby increasing the sensitivity of the assay (Wonderlich et al., 2019). Additionally, an in vivo VOA, whereby humanized mouse models are used to support viral outgrowth, has been shown to increase sensitivity and detect virus replication in samples that were previously negative when quantified using traditional VOA (Metcalf Pate et al., 2015; Charlins et al., 2017).

The ability to distinguish intact and defective provirus has made the VOA assay the gold standard method to measure the LR, thought this assay underestimates the size of the intact LR by $\sim 25$ to 60 -fold (Ho et al., 2013; Bruner et al., 2016). Genetic characterization of cells negative for viral outgrowth has revealed the presence of intact provirus, within active transcription units that is capable of generating replication competent virions following successive rounds of PHA stimulation (Ho et al., 2013; Hosmane et al., 2017). The mechanism underpinning the initial failure of these cells to generate viral outgrowth is likely the result of the stochastic nature of virus activation (Weinberger and Weinberger, 2013), nevertheless, their presence indicates an additional hurdle in both eradicating the LR and assessing the efficacy of eradication strategies. Of note, an extensive analysis of VOA performance using the same samples across different labs has indicated significant variability of results both within batches and between labs that is more pronounced in lower IUPM samples (Rosenbloom et al., 2019). This finding may have significant implications for HIV-1 cure research, where small differences in the replication competent reservoir must be accurately and reproducibly measured to assess the efficacy of therapeutic interventions. 
TABLE 1 | Different methods used to measure the latent reservoir.

\begin{tabular}{|c|c|c|c|c|}
\hline & Assay & Advantages & Disadvantages & Examples \\
\hline $\begin{array}{l}\text { Viral outgrowth } \\
\text { assay (VOA) }\end{array}$ & $\begin{array}{l}\text { Stimulated patient CD4 T cells in } \\
\text { limiting dilution grown with donor } \\
\text { cells and outgrowth measured }\end{array}$ & $\begin{array}{l}\text {-Only measures replication } \\
\text { competent provirus }\end{array}$ & $\begin{array}{l}\text {-Time consuming -Requires } \\
\text { large volumes of patient material } \\
\text {-Underestimate size of } \\
\text { the reservoir }\end{array}$ & $\begin{array}{l}\text { Finzi et al., } 1997 \\
\text { Siliciano and Siliciano, } 2005 \\
\text { Laird et al., } 2013 \\
\text { Bruner et al., } 2015 \\
\text { Fun et al., } 2017 \\
\text { Badia et al., } 2018 \\
\text { Massanella et al., } 2018 \\
\text { Wonderlich et al., } 2019\end{array}$ \\
\hline $\begin{array}{l}\text { Total HIV-1 } \\
\text { DNA qPCR }\end{array}$ & $\begin{array}{l}\text { Measures proviral DNA from cell } \\
\text { extracts using primers/probes in } \\
\text { conserved regions, primarily } \\
\text { within the LTR }\end{array}$ & $\begin{array}{l}\text {-Fast time from sample collection } \\
\text { to result } \\
\text {-Relatively inexpensive } \\
\text {-Small sample volume } \\
\text {-Can be used to detect different } \\
\text { DNA forms (2-LTR, integrated) }\end{array}$ & $\begin{array}{l}\text {-Cannot distinguish between } \\
\text { intact and defective provirus so } \\
\text { overestimates the reservoir } \\
\text {-Quantification relative to a } \\
\text { standard so prone to bias -Highly } \\
\text { specific and prone to error from } \\
\text { primer/template mismatches }\end{array}$ & $\begin{array}{l}\text { Kostrikis et al., } 2002 \\
\text { Beloukas et al., } 2009 \\
\text { van der Sluis et al., } 2013 \\
\text { Munir et al., } 2013 \\
\text { Casabianca et al., } 2014 \\
\text { Rouzioux et al., } 2014 \\
\text { Vandergeeten et al., } 2014 \\
\text { Thomas et al., } 2019\end{array}$ \\
\hline $\begin{array}{l}\text { Integrated } \\
\text { HIV-1 DNA }\end{array}$ & $\begin{array}{l}\text { Specifically measures only } \\
\text { integrated provirus using a primer } \\
\text { specific to HIV-1 and to Alu } \\
\text { sequences randomly dispersed in } \\
\text { the human genome }\end{array}$ & $\begin{array}{l}\text {-Measures the LR by excluding } \\
\text { unintegrated DNA forms } \\
\text {-Fast and relatively inexpensive }\end{array}$ & $\begin{array}{l}\text {-Distances between Alu and } \\
\text { HIV- } 1 \text { means } \sim 10 \% \text { of } \\
\text { integrated provirus is measured } \\
\text { - Heterogeneous nature of } \\
\text { integration sites means standard } \\
\text { design is complex }\end{array}$ & $\begin{array}{l}\text { Brussel et al., } 2005 \\
\text { Yu et al., } 2008 \\
\text { Liszewski et al., } 2009 \\
\text { Brady et al., } 2013 \\
\text { Agosto et al., } 2007 \\
\text { De Spiegelaere et al., } 2014 \\
\text { Vandergeeten et al., } 2014 \\
\text { Lada et al., } 2018\end{array}$ \\
\hline Digital PCR & $\begin{array}{l}\text { Measures frequency of proviral } \\
\text { DNA (integrated, total or circular) } \\
\text { by partitioning sample into limiting } \\
\text { dilutions and assigning partitions } \\
\text { either positive or negative }\end{array}$ & $\begin{array}{l}\text {-Eliminates the need for a } \\
\text { standard and so reduced bias } \\
\text { (especially useful for integrated } \\
\text { and 2-LTR circular DNA } \\
\text { quantifications) }\end{array}$ & $\begin{array}{l}\text {-More expensive and less widely } \\
\text { available than standard } \\
\text { qPCR methods } \\
\text {-Suffers from false-positives } \\
\text { inherent to the method } \\
\text {-Setting thresholds to determine } \\
\text { distinguish truly positive and } \\
\text { negative partitions is difficult }\end{array}$ & $\begin{array}{l}\text { De Spiegelaere et al., } 2014 \\
\text { Henrich et al., } 2012 \\
\text { Strain et al., } 2013 \\
\text { Malatinkova et al., } 2015 \\
\text { Henrich et al., } 2017 \\
\text { Lada et al., } 2018\end{array}$ \\
\hline $\begin{array}{l}\text { Cell associated } \\
\text { RNA }\end{array}$ & $\begin{array}{l}\text { Measures all or different forms of } \\
\text { cell associated RNA with the } \\
\text { rationale that it is more likely to } \\
\text { measure replication competent } \\
\text { provirus than defective }\end{array}$ & $\begin{array}{l}\text {-More sensitivity for replication } \\
\text { competent provirus }\end{array}$ & $\begin{array}{l}\text {-Cannot distinguish transcripts } \\
\text { that arise from replication } \\
\text { competent cells and defective } \\
\text { cells }\end{array}$ & $\begin{array}{l}\text { Archin et al., } 2012 \\
\text { Pasternak et al., } 2012 \\
\text { Shan et al., } 2013 \\
\text { Cillo et al., } 2014 \\
\text { Yucha et al., } 2017 \\
\text { Massanella et al., } 2018 \\
\text { Yukl et al., } 2018\end{array}$ \\
\hline TILDA & $\begin{array}{l}\text { Measures multiply spliced tat/rev } \\
\text { transcripts following stimulation of } \\
\text { CD4 T cells plated in limiting } \\
\text { dilution }\end{array}$ & $\begin{array}{l}\text {-Higher sensitivity for replication } \\
\text { competent provirus } \\
\text {-Faster, cheaper and less } \\
\text { resources needed than VOA }\end{array}$ & $\begin{array}{l}\text { Measured transcripts may arise } \\
\text { from defective proviral genomes }\end{array}$ & $\begin{array}{l}\text { Procopio et al., } 2015 \\
\text { Frank et al., } 2019 \\
\text { Bertoldi et al., } 2020\end{array}$ \\
\hline $\begin{array}{l}\text { ISH and flow } \\
\text { cytometry }\end{array}$ & $\begin{array}{l}\text { Measures mRNA and viral } \\
\text { proteins measured following } T \text { cell } \\
\text { activation }\end{array}$ & $\begin{array}{l}\text {-Higher sensitivity for replication } \\
\text { competent provirus } \\
\text {-Simultaneously phenotype the } \\
\text { cells that host the reservoir }\end{array}$ & $\begin{array}{l}\text {-Does not confirm that RNA or } \\
\text { proteins produced arise from } \\
\text { replication competent provirus }\end{array}$ & $\begin{array}{l}\text { Graf et al., } 2013 \\
\text { Baxter et al., 2016, } 2017 \\
\text { Martrus et al., } 2016 \\
\text { Grau-Expósito et al., } 2017 \\
\text { Deleage et al., 2018 } \\
\text { Pardons et al., 2019a }\end{array}$ \\
\hline IPDA & $\begin{array}{l}\text { Multiplex digital PCR based assay } \\
\text { to measure intact provirus based } \\
\text { on the presence of two regions } \\
\text { that are frequently mutated in the } \\
\text { viral genome }\end{array}$ & $\begin{array}{l}\text {-Enables distinction between } \\
\text { intact and defective provirus } \\
\text {-Faster readout than viral } \\
\text { outgrowth assay }\end{array}$ & $\begin{array}{l}\text {-Does not screen the whole } \\
\text { genome and may therefore miss } \\
\text { other deleterious mutations }\end{array}$ & Bruner et al., 2019 \\
\hline Q4PCR & $\begin{array}{l}\text { Multiplex qPCR assay to assign } \\
\text { replication competency based on } \\
\text { presence of } 4 \text { genomic regions, } \\
\text { confirmed by next generation } \\
\text { sequencing if } 2 / 4 \text { are present }\end{array}$ & $\begin{array}{l}\text {-Able to accurately distinguish } \\
\text { intact and defective provirus } \\
\text {-Filters out most defective } \\
\text { provirus before using expensive } \\
\text { sequencing }\end{array}$ & -Relatively expensive method & Gaebler et al., 2019 \\
\hline
\end{tabular}

The advantages and disadvantages of each approach as well as prominent examples. 


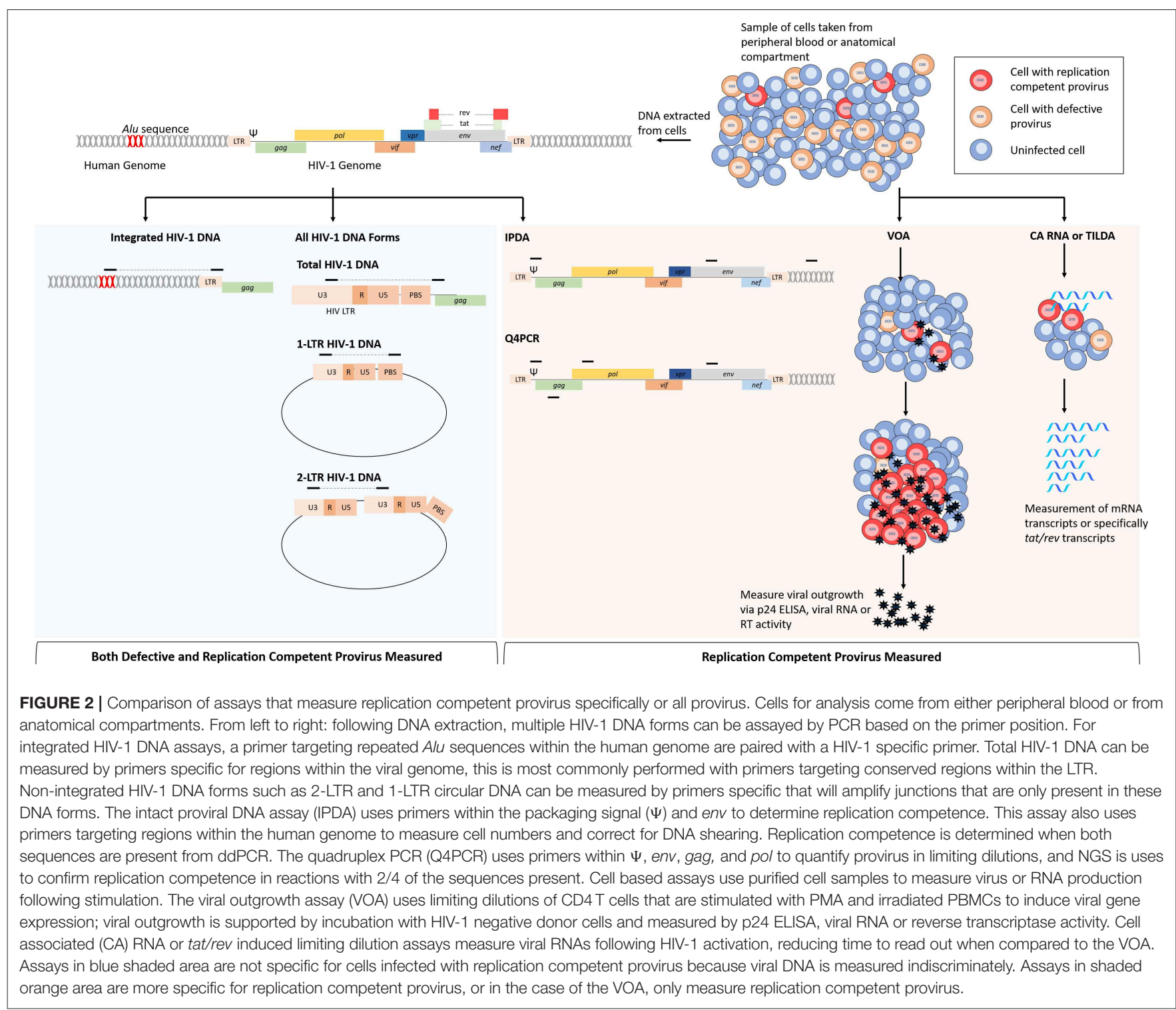

\section{qPCR Based HIV-1 Quantification}

Quantification of cell associated DNA by PCR provides a fast and relatively inexpensive marker to measure the size of the viral reservoir. HIV-1 DNA quantification methods rely on amplification of short genomic regions and so cannot distinguish intact and defective provirus and therefore vastly overestimate the size of the LR (Figure 2; Eriksson et al., 2013). Despite this limitation, HIV-1 DNA quantification has been shown to predict viral rebound (Williams et al., 2014) and offers the potential to identify different DNA forms, such as integrated HIV-1 DNA, non-integrated HIV-1 DNA (2-LTR and 1-LTR circular forms) or both (total HIV-1 DNA) (Mexas et al., 2012; Rouzioux and Avettand-Fenoël, 2018). Several factors affect the specificity, accuracy and reproducibly of HIV-1 DNA assays and as there is no standard method, meaningful comparison between different studies is limited. Currently, most HIV-1 DNA quantification assays utilize real-time quantitative PCR (qPCR) to measure the abundance of HIV-1 DNA relative to a calibration standard derived from cell lines harboring HIV-1 provirus. Cell lines such as $8 \mathrm{E} 5$ and $\mathrm{ACH} 2$ are widely used as the source of calibration DNA, though recent work has demonstrated that HIV-1 integration into these cell lines is unstable, likely due to ongoing replication, and their use may confound accurate quantification and reproducibility between labs (Sunshine et al., 2016; Wilburn et al., 2016; Busby et al., 2017; Symons et al., 2017; Rutsaert et al., 2018b; Thomas et al., 2019). Recent analysis of HIV-1 quantification methods has demonstrated the stability of HIV-1 integration into J-Lat 10.6, a Jurkat cell latently infected with full length, env deficient provirus, and suggested the use of this cell line as the gold standard for HIV-1 DNA quantification by qPCR (Sunshine et al., 2016; Thomas et al., 2019).

Another key determinant of the accuracy and specificity of HIV-1 DNA quantification assays is the genomic location at which the primers and probes anneal. The vast genetic 
variation of HIV-1 both within patients and across the epidemic necessitates appropriate selection of oligonucleotides that can efficiently amplify patient samples from a variety of sub-types and circulating recombinant forms (CRFs). Prominent assays have targeted various, highly conserved regions in the HIV-1 genome including gag (Kabamba-Mukadi et al., 2005; Kondo et al., 2009; Li et al., 2010) and pol (Désiré et al., 2001; Vitone et al., 2005). Nevertheless, the LTR region has been increasingly favored for HIV-1 DNA quantification because it is both highly conserved and facilitates the distinction between all of the various HIV-1 DNA forms (Kostrikis et al., 2002; Beloukas et al., 2009; Munir et al., 2013; van der Sluis et al., 2013; Casabianca et al., 2014; Rouzioux et al., 2014; Vandergeeten et al., 2014). Recently, an extensive in silico analysis of published HIV1 DNA assays revealed substantial variation between different methods, especially when comparing quantification of different HIV-1 subtypes, and indicated the best performing assays for quantification of diverse patient cohorts (Rutsaert et al., 2018b).

As discussed above, LTR based DNA assays can distinguish different HIV-1 DNA forms. During HIV-1 replication, linear unintegrated cDNA accumulates in the cell as well as abortive DNA forms such as 1-LTR and 2-LTR circular DNA, which are products of recombination events and interaction with host DNA repair mechanisms (Sloan and Wainberg, 2011; Munir et al., 2013). Because 2-LTR circular forms arise from failed integration, they are considered markers of recent infection and their quantification may therefore provide insight into the replication competent reservoir (Buzón et al., 2010; Hatano et al., 2013; Kiselinova et al., 2016). Conflicting evidence, however, suggests that these DNA forms may be persistent for long periods in latently infected cells and the clinical relevance of 2-LTR quantification remains controversial (Pierson et al., 2002).

To exclude unintegrated DNA forms from quantification, it is possible to amplify specifically integrated provirus by targeting an endogenous Alu sequence that are found randomly across the human genome (Figure 2). Generally, Alu PCR assays utilize a nested approach in which the junction between an HIV1 sequence and a human Alu sequence is amplified, followed by qPCR with primers specific to HIV-1 (Brussel et al., 2005; Agosto et al., 2007; Liszewski et al., 2009; Brady et al., 2013; De Spiegelaere et al., 2014; Vandergeeten et al., 2014; Ruggiero et al., 2017). Alu PCR remains the most common approach to measure integrated HIV-1 DNA, though alternative methods have been developed as reviewed here (Liszewski et al., 2009; Ruggiero et al., 2017). Whilst the Alu PCR assay has been shown to correlate well with the VOA (Eriksson et al., 2013), it is hindered by limitations in accuracy and sensitivity that are inherent to the method. The random dispersion of human Alu sequences, as well as the heterogeneity of HIV-1 integration sites, means that the sequence length between the Alu and HIV-1 specific primers is unknown and variable; presenting several technical challenges that may confound accurate quantification of proviral DNA (Brady et al., 2013). Cell lines used as quantification standards, for example, are generally derived from clonal, latently infected cells and therefore do not represent the random nature of integration within a patient sample (Ruggiero et al., 2017). To overcome this issue, researchers have developed a calibration standard containing multiple integration sites to resemble more closely the sample population (Agosto et al., 2007). Alternatively, the reliance on a standard may be circumvented by the use of repetitive sampling and absolute quantification based on Poisson distribution (De Spiegelaere et al., 2014). Additionally, only $10 \%$ of integrated HIV -1 is detected by this assay because $90 \%$ of integrated provirus is too far from an Alu sequence to be exponentially amplified and a correction factor must therefore be applied to the quantification (Agosto et al., 2007; Yu et al., 2008; Liszewski et al., 2009; De Spiegelaere et al., 2014). Accuracy is further limited by linear amplification of unintegrated HIV1 DNA, though the effect of this can be partially negated by simultaneous pre-amplification with only the HIV-1 specific primer to enable distinction between integrated and unintegrated DNA (O'Doherty et al., 2002; Yu et al., 2008) or by pulsed-field gel electrophoresis (PFGE) prior to amplification to remove low molecular weight DNA (Lada et al., 2018). Despite its limitations and owing to the various improvements made, quantification integrated HIV-1 via Alu PCR is a powerful and high-throughput method to quantify the LR. An improved Alu PCR assay, where the HIV-1 LTR primer is closer to the integration junction and therefore detects more integration events, is currently in development (Personal Communication).

\section{Digital Droplet PCR Based HIV-1 Quantification}

As discussed above, the selection of an appropriate calibration standard is required for quantification of HIV-1 DNA, however, quantification relative to a standard is inherently biased. Amplification efficiencies between the standard and the sample must be equal to limit bias when quantifying relative to a standard curve (Rutsaert et al., 2018a). Amplification efficiency is affected by the DNA input per reaction, the presence of inhibitory contaminants and, crucially for HIV-1 quantification, recent work has shown that small mismatches between the primer and target sequence significantly impair sample quantification (Rutsaert et al., 2018b; Thomas et al., 2019). Digital droplet PCR (ddPCR) platforms mitigate these issues by facilitating absolute quantification of a sample and as such, are becoming increasingly popular in $\mathrm{HIV}-1$ research and clinical trials. In ddPCR, samples are randomly divided into multiple partitions and separately amplified, after which each partition is deemed positive or negative based on fluorescence above or below a threshold and absolute quantification is determined based on Poisson distribution (Hindson et al., 2011). In principle, the use of ddPCR to eliminate the need for a standard reduces these biases because each partition only needs to accumulate enough fluorescence to be deemed positive, so factors that reduce PCR efficiency should not impair the accuracy of quantification. The major limitation of ddPCR, however, is the difficulty to accurately determine the threshold above which a partition can be deemed positive (Rutsaert et al., 2018a). Partitions in which intermediate fluorescence is observed may be incorrectly assigned as positive or negative if the threshold selection is not sufficiently robust and a number of approaches to determine the threshold have been developed to overcome this issue, reviewed in detail here 
(Rutsaert et al., 2018a). Additionally, even with robust threshold selection, ddPCR is known to suffer from a high frequency of false-positive results (Henrich et al., 2012; Strain et al., 2013; Kiselinova et al., 2014; Bosman et al., 2015; Trypsteen et al., 2015). False-positives are likely the result of combined droplets resulting in increased fluorescence or from DNA contamination that is difficult to distinguish from truly positive samples (Henrich et al., 2012; Strain et al., 2013; Kiselinova et al., 2014; Bosman et al., 2015; Trypsteen et al., 2015). Despite these limitations, the use of ddPCR has proven an invaluable tool for measuring HIV-1 DNA and has been used successfully in various studies (De Spiegelaere et al., 2014; Malatinkova et al., 2015; Henrich et al., 2017).

\section{Bridging the Gap Between Culture and PCR Based Assays}

Given that the majority of HIV-1 DNA is replication deficient, PCR based assays vastly overestimate the size of the latent reservoir (Eriksson et al., 2013; Ho et al., 2013). Conversely, the VOA is known to underestimate the size of the LR due to the presence of intact non-induced proviruses and so both methods may confound the assessment of treatment and cure strategies (Eriksson et al., 2013; Ho et al., 2013). Several assays have been developed with the aim to bridge the gap between these two types of analyses by providing a fast and relatively inexpensive method to specifically quantify only replication competent provirus. In a method conceptually similar to the VOA, cell associated (CA) HIV-1 RNA quantification following CD4 T cell activation has been used to measure the size of the inducible LR (Figure 2; Archin et al., 2012; Pasternak et al., 2012; Shan et al., 2013; Cillo et al., 2014; Yucha et al., 2017; Massanella et al., 2018; Yukl et al., 2018). The measurement of CA RNA provides the opportunity to quantify different transcripts and therefore, different stages of the replication cycle that may be used as a surrogate for measuring the size of the intact LR (Cillo et al., 2014; Massanella et al., 2018; Pasternak and Berkhout, 2018; Yukl et al., 2018). However, cells harboring defective provirus are still capable of producing HIV-1 mRNA following T cell activation despite being unable to generate infectious virions, and so these methods are prone to false positive results (Hermankova et al., 2003; Pasternak et al., 2009; Schmid et al., 2010; Cillo et al., 2014). By measuring cell-free HIV-1 RNA from culture supernatant, indicative of virus release from cells, as well as CA RNA, it is possible to more closely predict replication competence (Cillo et al., 2014; Massanella et al., 2018). In addition, a novel assay has addressed this issue by specifically measuring tat/rev multiply spliced mRNAs with the rationale that these transcripts are rarely produced in cells with defective HIV-1 provirus (Figure 2; Procopio et al., 2015; Frank et al., 2019; Bertoldi et al., 2020). The tat/rev induced limiting dilution assay (TILDA) relies on measurement of tat/rev transcripts from cells plated in limiting dilution, following activation with phorbol 12-myristate 13acetate (PMA) and ionomycin (Procopio et al., 2015). Results obtained from TILDA quantification correlated well with HIV-1 DNA quantification and measures the LR close to levels predicted by Ho et al. (2013) and Procopio et al. (2015). This method, however, did not significantly correlate with results obtained from VOA and is still susceptible to overestimating the size of the LR due to the possibility that these transcripts arise from cells with defective HIV-1 genomes (Procopio et al., 2015).

Other groups have sought to quantify the replication competent reservoir using in situ hybridization (ISH) and flow cytometry to measure CA RNA or capsid p24 protein (Graf et al., 2013; Baxter et al., 2016, 2017; Martrus et al., 2016; GrauExpósito et al., 2017; Deleage et al., 2018; Pardons et al., 2019a). By combining flow cytometry based quantification of CA RNA and p24 capsid protein, it is possible to measure provirus that is capable of transcription as well as protein production, providing a close surrogate for the measurement of the intact LR (Baxter et al., 2016, 2017, 2018; Martrus et al., 2016; Grau-Expósito et al., 2017; Puray-Chavez et al., 2017). An additional benefit of flow cytometry based approaches is the opportunity to simultaneously infer phenotypic characteristics of the cell populations that host the replication competent reservoir, as reviewed (Baxter et al., 2018).

More recently, a novel assay known as the intact proviral DNA assay (IPDA) has demonstrated the use of a multiplexed ddPCR approach to measure the size of the intact LR based on the presence of regions that are frequently mutated in defective genomes (Figure 2; Bruner et al., 2019). In this assay, intact and defective proviruses are separately quantified by amplifying regions within the HIV-1 packaging signal $(\Psi)$ and env and the presence or absence of these regions is sufficient to distinguish $90 \%$ of defective genomes (Bruner et al., 2019). By determining replication competence based on DNA composition, this assay is not dependent on $\mathrm{T}$ cell stimulation and is therefore not impaired by the presence of non-inducible, intact proviruses that contribute to LR underestimation in the VOA (Bruner et al., 2015, 2016). Despite this, the IPDA is still only able to distinguish $90 \%$ of defective proviruses, with mutations that occur in non-amplified regions counting toward the quantification. Additionally, like all PCR based HIV-1 assays, primer mismatches in target regions may result in false negative quantifications. Similarly, Gaebler et al., recently described an approach (Q4PCR) that uses multiplexed qPCR measurement of four proviral regions; gag, pol, env, and $\Psi$, followed by next generation sequencing (NGS) of samples that are positive for two out of four regions to confirm replication competence (Figure 2; Gaebler et al., 2019). In comparison with IPDA, the Q4PCR method offers increased accuracy to predict replication competence due to a higher percentage of the viral genome being interrogated and likely positive samples being validated via NGS (Gaebler et al., 2019). Nevertheless, this increased sensitivity does come with the increased cost and lower throughput associated with NGS.

Previously, full-length sequencing of proviral DNA has provided invaluable insight into the composition of the LR (Ho et al., 2013) but the methods used are time consuming and technically challenging. The advent of various NGS technologies, however, has also paved the way for novel methods to measure the HIV-1 LR with relative ease and high throughput (Lambrechts et al., 2020). The use of Illumina based sequencing techniques has so far been used in LR studies to measure fulllength, individual proviral sequences, helping to elucidate the 
driving force of LR persistence and latency maintenance (Hiener et al., 2017; Lee et al., 2017; Einkauf et al., 2019). Further, the emergence of NGS technologies that can sequence longreads, such as PacBio's SMRT Sequencing and Oxford Nanopore's MinION, may be employed to measure full-length proviral genomes or variant transcript forms from patient samples and are likely to lead to advances in our understanding of the LR.

\section{CONCLUSIONS}

The use of antiretroviral therapy has succeeded in reducing HIV-1 mortality but cannot eliminate the virus due to the persistent and stable LR. The global disease burden, equating to $\sim 36$ million infected individuals of which $\sim 22$ million have access to ART, warrants the continued search for a therapeutic approach that can either eliminate the virus or induce sustained viral remission in the absence of therapy (Sung et al., 2018). Recent advances in our understanding of the LR, its cellular and anatomical hosts and the mechanisms that facilitate its long-term persistence have contributed to renewed hope of a curative intervention for HIV-1 infection. Generally, an HIV-1 cure should eliminate the possibility of viral rebound following treatment interruption, and this relies on drastic reduction in the LR and efficient immune mediated clearance of HIV-1 infected cells.

Currently, several approaches for HIV-1 cure have been proposed and trialed to varying degrees of success. One of the most prominent cure strategies, "shock and kill," has demonstrated virus reactivation in vivo, but has been unable to lead to a meaningful increase in the time to viral rebound;

\section{REFERENCES}

Abdel-Mohsen, M., Kuri-Cervantes, L., Grau-Exposito, J., Spivak, A. M., Nell, R. A., Tomescu, C., et al. (2018). CD32 is expressed on cells with transcriptionally active HIV but does not enrich for HIV DNA in resting T cells. Sci. Transl. Med. 10:eaar6759. doi: 10.1126/scitranslmed.aar6759

Abner, E., and Jordan, A. (2019). HIV "shock and kill" therapy: in need of revision. Antiviral Res. 166, 19-34. doi: 10.1016/j.antiviral.2019. 03.008

Agosto, L. M., Herring, M. B., Mothes, W., and Henderson, A. J. (2018). HIV-1infected CD4+ T cells facilitate latent infection of resting CD4+ T cells through cell-cell contact. Cell Rep. 24, 2088-2100. doi: 10.1016/j.celrep.2018.07.079

Agosto, L. M., Yu, J. J., Dai, J., Kaletsky, R., Monie, D., and O’Doherty, U. (2007). HIV-1 integrates into resting CD4 $+\mathrm{T}$ cells even at low inoculums as demonstrated with an improved assay for HIV-1 integration. Virology 368, 60-72. doi: 10.1016/j.virol.2007.06.001

Ahlenstiel, C., Mendez, C., Lim, S. T. H., Marks, K., Turville, S., Cooper, D. A., et al. (2015). Novel RNA duplex locks HIV-1 in a latent state via chromatin-mediated transcriptional silencing. Mol. Ther. Nucleic Acids 4:e261. doi: 10.1038/mtna.2015.31

Aid, M., Dupuy, F. P., Moysi, E., Moir, S., Haddad, E. K., Estes, J. D., et al. (2018). Follicular CD4 T helper cells as a major HIV reservoir compartment: a molecular perspective. Front. Immunol. 9:895. doi: 10.3389/fimmu.2018.00895

Albert, B. J., Niu, A., Ramani, R., Marshall, G. R., Wender, P. A., Williams, R. M., et al. (2017). Combinations of isoform-targeted histone deacetylase inhibitors and bryostatin analogues display remarkable potency to activate latent HIV without global T-cell activation. Sci. Rep. 7:7456. doi: 10.1038/s41598-017-07814-4 suggesting improvement is required to aid the "killing" of infected cells. Alternative approaches, such as therapeutic vaccination, aim to prime the immune response to HIV-1 infection with the rationale that upon treatment interruption, immune mediated control of the virus will be improved. Several new technologies and approaches, such as immune checkpoint inhibitors, gene editing and CAR-T cells may offer an alternative method for cure, though currently their assessment in clinical trials is limited. An added complication in the search for an HIV-1 cure is the difficulty in accurately measuring the success of such trials. The inherent variability of the HIV-1 genome, the low frequency of latently infected cells as well as the abundance of defective provirus contribute to the complexity of LR quantification.

Rather than an improvement in the current strategies leading to a cure, it is likely that synergistic combinations of different approaches, such as the use of LRAs following therapeutic vaccination, will lead to more drastic reductions in the LR and may aid the ultimate goal of long term ART free viral remission.

\section{AUTHOR CONTRIBUTIONS}

JT conceptualized and outlined the manuscript and wrote the first draft. AR, WP, and GP contributed to editing the manuscript. All authors approved the final version.

\section{FUNDING}

This work was partly funded under EU Horizon 2020 program under grant agreement number 681032 (EHVA).
Ali, A., Kitchen, S. G., Chen, I. S. Y., Ng, H. L., Zack, J. A., and Yang, O. O. (2016). HIV-1-specific chimeric antigen receptors based on broadly neutralizing antibodies. J. Virol. 90, 6999-7006. doi: 10.1128/JVI.00805-16

Alvarez, Y., Tuen, M., Shen, G., Nawaz, F., Arthos, J., Wolff, M. J., et al. (2013). Preferential HIV infection of CCR6+ Th17 cells is associated with higher levels of virus receptor expression and lack of CCR5 ligands. J. Virol. 87, 10843-10854. doi: 10.1128/JVI.01838-13

Alvarez-Carbonell, D., Garcia-Mesa, Y., Milne, S., Das, B., Dobrowolski, C., Rojas, R., et al. (2017). Toll-like receptor 3 activation selectively reverses HIV latency in microglial cells. Retrovirology 14:9. doi: 10.1186/s12977-017-0335-8

Ananworanich, J., and Robb, M. L. (2014). The transient HIV remission in the Mississippi baby: why is this good news? J. Int. AIDS Soc. 17:19859. doi: 10.7448/IAS.17.1.19859

Anderson, J. A., Archin, N. M., Ince, W., Parker, D., Wiegand, A., Coffin, J. M., et al. (2011). Clonal sequences recovered from plasma from patients with residual HIV-1 viremia and on intensified antiretroviral therapy are identical to replicating viral RNAs recovered from circulating resting CD4+ T cells. J. Virol. 85, 5220-5223. doi: 10.1128/JVI.00284-11

Anthony-Gonda, K., Bardhi, A., Ray, A., Flerin, N., Li, M., Chen, W., et al. (2019). Multispecific anti-HIV duoCAR-T cells display broad in vitro antiviral activity and potent in vivo elimination of HIV-infected cells in a humanized mouse model. Sci. Transl. Med. 11:eaav5685. doi: 10.1126/scitranslmed.aav5685

Archin, N. M., Bateson, R., Tripathy, M. K., Crooks, A. M., Yang, K.-H., Dahl, N. P., et al. (2014a). HIV-1 expression within resting CD4+ T cells after multiple doses of vorinostat. J. Infect. Dis. 210, 728-735. doi: 10.1093/infdis/jiu155

Archin, N. M., Kirchherr, J. L., Sung, J. A., Clutton, G., Sholtis, K., Xu, Y., et al. (2017). Interval dosing with the HDAC inhibitor vorinostat effectively reverses HIV latency. J. Clin. Invest. 127, 3126-3135. doi: 10.1172/JCI92684 
Archin, N. M., Liberty, A. L., Kashuba, A. D., Choudhary, S. K., Kuruc, J. D., Crooks, A. M., et al. (2012). Administration of vorinostat disrupts HIV-1 latency in patients on antiretroviral therapy. Nature 487, 482-485. doi: 10.1038/nature11286

Archin, N. M., Sung, J. M., Garrido, C., Soriano-Sarabia, N., and Margolis, D. M. (2014b). Eradicating HIV-1 infection: seeking to clear a persistent pathogen. Nat. Rev. Microbiol. 12, 750-764. doi: 10.1038/nrmicro3352

Badia, R., Ballana, E., Castellví, M., García-Vidal, E., Pujantell, M., Clotet, B., et al. (2018). CD32 expression is associated to T-cell activation and is not a marker of the HIV-1 reservoir. Nat. Commun. 9:2739. doi: 10.1038/s41467-018-05157-w

Bailey, J. R., Sedaghat, A. R., Kieffer, T., Brennan, T., Lee, P. K., Wind-Rotolo, M., et al. (2006). Residual human immunodeficiency virus type 1 viremia in some patients on antiretroviral therapy is dominated by a small number of invariant clones rarely found in circulating CD4+ T Cells. J. Virol. 80, 6441-6457. doi: 10.1128/JVI.00591-06

Baldauf, H.-M., Pan, X., Erikson, E., Schmidt, S., Daddacha, W., Burggraf, M., et al. (2012). SAMHD1 restricts HIV-1 infection in resting CD4+ T cells. Nat. Med. 18, 1682-1688. doi: 10.1038/nm.2964

Banga, R., Procopio, F. A., Noto, A., Pollakis, G., Cavassini, M., Ohmiti, K., et al. (2016). PD-1 (+) and follicular helper T cells are responsible for persistent HIV-1 transcription in treated aviremic individuals. Nat. Med. 22, 754-761. doi: $10.1038 / \mathrm{nm} .4113$

Banga, R., Procopio, F. A., Ruggiero, A., Noto, A., Ohmiti, K., Cavassini, M., et al. (2018). Blood CXCR3 + CD4 T Cells are enriched in inducible replication competent HIV in aviremic antiretroviral therapy-treated individuals. Front. Immunol. 9:144. doi: 10.3389/fimmu.2018.00144

Banga, R., Rebecchini, C., Procopio, F. A., Noto, A., Munoz, O., Ioannidou, K., et al. (2019). Lymph node migratory dendritic cells modulate HIV1 transcription through PD-1 engagement. PLoS Pathog. 15:e1007918. doi: 10.1371/journal.ppat.1007918

Baxter, A. E., Niessl, J., Fromentin, R., Richard, J., Porichis, F., Charlebois, R., et al. (2016). Single-cell characterization of viral translation-competent reservoirs in HIV-infected individuals. Cell Host Microbe 20, 368-380. doi: 10.1016/j.chom.2016.07.015

Baxter, A. E., Niessl, J., Fromentin, R., Richard, J., Porichis, F., Massanella, M., et al. (2017). Multiparametric characterization of rare HIV-infected cells using an RNA-flow FISH technique. Nat. Protoc. 12, 2029-2049. doi: $10.1038 /$ nprot.2017.079

Baxter, A. E., O’Doherty, U., and Kaufmann, D. E. (2018). Beyond the replicationcompetent HIV reservoir: transcription and translation-competent reservoirs. Retrovirology 15:18. doi: 10.1186/s12977-018-0392-7

Bella, R., Kaminski, R., Mancuso, P., Young, W.-B., Chen, C., Sariyer, R., et al. (2018). Removal of HIV DNA by CRISPR from patient blood engrafts in humanized mice. Mol. Ther. Nucleic Acids 12, 275-282. doi: 10.1016/j.omtn.2018.05.021

Beloukas, A., Paraskevis, D., Haida, C., Sypsa, V., and Hatzakis, A. (2009). Development and assessment of a multiplex real-time PCR assay for quantification of human immunodeficiency virus type 1 DNA. J. Clin. Microbiol. 47, 2194-2199. doi: 10.1128/JCM.01264-08

Bertagnolli, L. N., White, J. A., Simonetti, F. R., Beg, S. A., Lai, J., Tomescu, C., et al. (2018). The role of CD32 during HIV-1 infection. Nature 561, E17-E19. doi: 10.1038/s41586-018-0494-3

Bertoldi, A., D’Urbano, V., Bon, I., Verbon, A., Rokx, C., Boucher, C., et al. (2020). Development of C-TILDA: a modified TILDA method for reservoir quantification in long term treated patients infected with subtype C HIV-1. J. Virol. Methods 276:113778. doi: 10.1016/j.jviromet.2019.113778

Boliar, S., Gludish, D. W., Jambo, K. C., Kamng’ona, R., Mvaya, L., Mwandumba, H. C., et al. (2019). Inhibition of the IncRNA SAF drives activation of apoptotic effector caspases in HIV-1-infected human macrophages. Proc. Natl. Acad. Sci. U.S.A. 116, 7431-7438. doi: 10.1073/pnas.1818662116

Borducchi, E. N., Cabral, C., Stephenson, K. E., Liu, J., Abbink, P., Ng’ang’a, D., et al. (2016). Ad26/MVA therapeutic vaccination with TLR7 stimulation in SIV-infected rhesus monkeys. Nature 540, 284-287. doi: 10.1038/nature20583

Bosman, K. J., Nijhuis, M., van Ham, P. M., Wensing, A. M. J., Vervisch, K., Vandekerckhove, L., et al. (2015). Comparison of digital PCR platforms and semi-nested qPCR as a tool to determine the size of the HIV reservoir. Sci. Rep. 5:13811. doi: $10.1038 /$ srep 13811
Boyer, Z., and Palmer, S. (2018). Targeting immune checkpoint molecules to eliminate latent HIV. Front. Immunol. 9:2339. doi: 10.3389/fimmu.2018.02339

Bozzi, G., Simonetti, F. R., Watters, S. A., Anderson, E. M., Gouzoulis, M., Kearney, M. F., et al. (2019). No evidence of ongoing HIV replication or compartmentalization in tissues during combination antiretroviral therapy: implications for HIV eradication. Sci. Adv. 5:eaav2045 doi: 10.1126/sciadv.aav2045

Brady, T., Kelly, B. J., Male, F., Roth, S., Bailey, A., Malani, N., et al. (2013). Quantitation of HIV DNA integration: effects of differential integration site distributions on Alu-PCR assays. J. Virol. Methods 189, 53-57. doi: 10.1016/j.jviromet.2013.01.004

Bruner, K. M., Hosmane, N. N., and Siliciano, R. F. (2015). Towards an HIV-1 cure: measuring the latent reservoir. Trends Microbiol. 23, 192-203. doi: 10.1016/j.tim.2015.01.013

Bruner, K. M., Murray, A. J., Pollack, R. A., Soliman, M. G., Laskey, S. B., Capoferri, A. A., et al. (2016). Defective proviruses rapidly accumulate during acute HIV-1 infection. Nat. Med. 22, 1043-1049. doi: 10.1038/nm.4156

Bruner, K. M., Wang, Z., Simonetti, F. R., Bender, A. M., Kwon, K. J., Sengupta, S., et al. (2019). A quantitative approach for measuring the reservoir of latent HIV-1 proviruses. Nature 566, 120-125. doi: 10.1038/s41586-019-0898-8

Brussel, A., Delelis, O., and Sonigo, P. (2005). "Alu-LTR real-time nested PCR assay for quantifying integrated HIV-1 DNA," in Methods in Molecular Biology (Clifton, N.J.), ed T. Zhu (Totowa, NJ: Humana Press), 139-154. doi: 10.1385/1-59259-907-9:139

Busby, E., Whale, A. S., Bridget Ferns, R., Grant, P. R., Morley, G., Campbell, J., et al. (2017). Instability of $8 \mathrm{E} 5$ calibration standard revealed by digital PCR risks inaccurate quantification of HIV DNA in clinical samples by qPCR. Sci. Rep. 7:1209. doi: 10.1038/s41598-017-01221-5

Buzón, M. J., Massanella, M., Llibre, J. M., Esteve, A., Dahl, V., Puertas, M. C., et al. (2010). HIV-1 replication and immune dynamics are affected by raltegravir intensification of HAART-suppressed subjects. Nat. Med. 16, 460-465. doi: 10.1038/nm.2111

Buzon, M. J., Sun, H., Li, C., Shaw, A., Seiss, K., Ouyang, Z., et al. (2014). HIV1 persistence in CD4+ T cells with stem cell-like properties. Nat. Med. 20, 139-142. doi: 10.1038/nm.3445

Caruso, M. P., Falivene, J., Holgado, M. P., Zurita, D. H., Laufer, N., Castro, C., et al. (2019). Impact of HIV-ART on the restoration of Th17 and Treg cells in blood and female genital mucosa. Sci. Rep. 9:1978. doi: 10.1038/s41598-019-38547-1

Cary, D. C., Fujinaga, K., and Peterlin, B. M. (2016). Molecular mechanisms of HIV latency. J. Clin. Invest. 126, 448-454. doi: 10.1172/JCI80565

Casabianca, A., Orlandi, C., Canovari, B., Scotti, M., Acetoso, M., Valentini, M., et al. (2014). A real time PCR platform for the simultaneous quantification of total and extrachromosomal HIV DNA forms in blood of HIV-1 infected patients. PLoS ONE 9:e111919. doi: 10.1371/journal.pone.0111919

Castellano, P., Prevedel, L., and Eugenin, E. A. (2017). HIV-infected macrophages and microglia that survive acute infection become viral reservoirs by a mechanism involving Bim. Sci. Rep. 7:12866. doi: 10.1038/s41598-017-12758-w

Centlivre, M., Legrand, N., Steingrover, R., van der Sluis, R., Grijsen, M. L., Bakker, M., et al. (2011). Altered dynamics and differential infection profiles of lymphoid and myeloid cell subsets during acute and chronic HIV-1 infection. J. Leukoc. Biol. 89, 785-795. doi: 10.1189/jlb.04 10231

Charlins, P., Schmitt, K., Remling-Mulder, L., Hogan, L. E., Hanhauser, E., Hobbs, K. S., et al. (2017). A humanized mouse-based HIV-1 viral outgrowth assay with higher sensitivity than in vitro qVOA in detecting latently infected cells from individuals on ART with undetectable viral loads. Virology 507, 135-139. doi: 10.1016/j.virol.2017.04.011

Chomont, N., El-Far, M., Ancuta, P., Trautmann, L., Procopio, F. A., Yassine-Diab, B., et al. (2009). HIV reservoir size and persistence are driven by T cell survival and homeostatic proliferation. Nat. Med. 15, 893-900. doi: 10.1038/nm.1972

Chomont, N., Okoye, A. A., Favre, D., and Trautmann, L. (2018). Wake me up before you go: a strategy to reduce the latent HIV reservoir. AIDS 32, 293-298. doi: 10.1097/QAD.0000000000001695

Christensen-Quick, A., Lafferty, M., Sun, L., Marchionni, L., DeVico, A., and Garzino-Demo, A. (2016). Human Th17 cells lack HIV-inhibitory RNases and are highly permissive to productive HIV infection. J. Virol. 90, 7833-7847. doi: 10.1128/JVI.02869-15 
Chun, T.-W., Davey, R. T., Engel, D., Lane, H. C., and Fauci, A. S. (1999). Re-emergence of HIV after stopping therapy. Nature 401, 874-875. doi: $10.1038 / 44755$

Chun, T.-W., Finzi, D., Margolick, J., Chadwick, K., Schwartz, D., and Siliciano, R. F. (1995). In vivo fate of HIV-1-infected T cells: quantitative analysis of the transition to stable latency. Nat. Med. 1, 1284-1290. doi: 10.1038/nm1295-1284

Chun, T.-W., Nickle, D. C., Justement, J. S., Meyers, J. H., Roby, G., Hallahan, C. W., et al. (2008). Persistence of HIV in gut-associated lymphoid tissue despite long-term antiretroviral therapy. J. Infect. Dis. 197, 714-720. doi: $10.1086 / 527324$

Chun, T. W., Engel, D., Berrey, M. M., Shea, T., Corey, L., and Fauci, A. S. (1998). Early establishment of a pool of latently infected, resting CD4+ T cells during primary HIV-1 infection. Proc. Natl. Acad. Sci. U.S.A. 95, 8869-8873. doi: $10.1073 /$ pnas.95.15.8869

Chun, T. W., Stuyver, L., Mizell, S. B., Ehler, L. A., Mican, J. A. M., Baseler, M., et al. (1997). Presence of an inducible HIV-1 latent reservoir during highly active antiretroviral therapy. Proc. Natl. Acad. Sci. U.S.A. 94, 13193-13197. doi: $10.1073 /$ pnas.94.24.13193

Churchill, M. J., Deeks, S. G., Margolis, D. M., Siliciano, R. F., and Swanstrom, R. (2016). HIV reservoirs: what, where and how to target them. Nat. Rev. Microbiol. 14, 55-60. doi: 10.1038/nrmicro.2015.5

Cillo, A. R., Sobolewski, M. D., Bosch, R. J., Fyne, E., Piatak, M., Coffin, J. M., et al. (2014). Quantification of HIV-1 latency reversal in resting CD4+ T cells from patients on suppressive antiretroviral therapy. Proc. Natl. Acad. Sci. U.S.A. 111, 7078-7083. doi: 10.1073/pnas.1402873111

Clayton, K. L., Collins, D. R., Lengieza, J., Ghebremichael, M., Dotiwala, F., Lieberman, J., et al. (2018). Resistance of HIV-infected macrophages to CD8+ T lymphocyte-mediated killing drives activation of the immune system. Nat. Immunol. 19, 475-486. doi: 10.1038/s41590-018-0085-3

Clutton, G. T., and Jones, R. B. (2018). Diverse impacts of HIV latency-reversing agents on CD8+ T-cell function: implications for HIV cure. Front. Immunol. 9:1452. doi: 10.3389/fimmu.2018.01452

Cohn, L. B., Silva, I. T., Oliveira, T. Y., Rosales, R. A., Parrish, E. H., Learn, G. H., et al. (2015). HIV-1 integration landscape during latent and active infection. Cell 160, 420-432. doi: 10.1016/j.cell.2015.01.020

Colby, D. J., Trautmann, L., Pinyakorn, S., Leyre, L., Pagliuzza, A., Kroon, E., et al. (2018). Rapid HIV RNA rebound after antiretroviral treatment interruption in persons durably suppressed in Fiebig I acute HIV infection. Nat. Med. 24, 923-926. doi: 10.1038/s41591-018-0026-6

Crooks, A. M., Bateson, R., Cope, A. B., Dahl, N. P., Griggs, M. K., Kuruc, J. D., et al. (2015). Precise quantitation of the latent HIV-1 reservoir: implications for eradication strategies. J. Infect. Dis. 212, 1361-1365. doi: 10.1093/infdis/jiv218

Darcis, G., Kootstra, N. A., Hooibrink, B., van Montfort, T., Maurer, I., Groen, K., et al. (2020). CD32+CD4+ T cells are highly enriched for HIV DNA and can support transcriptional latency. Cell Rep. 30, 2284-2296.e3. doi: 10.1016/j.celrep.2020.01.071

Darcis, G., Kula, A., Bouchat, S., Fujinaga, K., Corazza, F., Ait-Ammar, A., et al. (2015). An in-depth comparison of latency-reversing agent combinations in various in vitro and ex vivo HIV-1 latency models identified bryostatin-1+JQ1 and ingenol-B+JQ1 to potently reactivate viral gene expression. PLoS Pathog. 11:e1005063. doi: 10.1371/journal.ppat.1005063

Dash, P. K., Kaminski, R., Bella, R., Su, H., Mathews, S., Ahooyi, T. M., et al. (2019). Sequential LASER ART and CRISPR treatments eliminate HIV-1 in a subset of infected humanized mice. Nat. Commun. 10:2753. doi: 10.1038/s41467-019-10366-y

Davenport, M. P., Khoury, D. S., Cromer, D., Lewin, S. R., Kelleher, A. D., and Kent, S. J. (2019). Functional cure of HIV: the scale of the challenge. Nat. Rev. Immunol. 19, 45-54. doi: 10.1038/s41577-018-0085-4

Davey, R. T., Bhat, N., Yoder, C., Chun, T. W., Metcalf, J. A., Dewar, R., et al. (1999). HIV-1 and $\mathrm{T}$ cell dynamics after interruption of highly active antiretroviral therapy (HAART) in patients with a history of sustained viral suppression. Proc. Natl. Acad. Sci. U.S.A. 96, 15109-15114. doi: 10.1073/pnas.96.26.15109

De Scheerder, M.-A., Vrancken, B., Dellicour, S., Schlub, T., Lee, E., Shao, W., et al. (2019). HIV rebound is predominantly fueled by genetically identical viral expansions from diverse reservoirs. Cell Host Microbe 26, 347-358.e7. doi: 10.1016/j.chom.2019.08.003

De Spiegelaere, W., Malatinkova, E., Lynch, L., van Nieuwerburgh, F., Messiaen, P., O'Doherty, U., et al. (2014). Quantification of integrated HIV DNA by repetitive-sampling Alu-HIV PCR on the basis of poisson statistics. Clin. Chem. 60, 886-895. doi: 10.1373/clinchem.2013.219378

Deeks, S. G. (2012). Shock and kill. Nature 487, 439-440. doi: 10.1038/487439a

Delagrèverie, H. M., Delaugerre, C., Lewin, S. R., Deeks, S. G., and Li, J. Z. (2016). Ongoing clinical trials of human immunodeficiency virus latencyreversing and immunomodulatory agents. Open Forum Infect. Dis. 3:ofw189. doi: 10.1093/ofid/ofw189

Deleage, C., Chan, C. N., Busman-Sahay, K., and Estes, J. D. (2018). Next-generation in situ hybridization approaches to define and quantify HIV and SIV reservoirs in tissue microenvironments. Retrovirology 15:4. doi: 10.1186/s12977-017-0387-9

Deng, K., Pertea, M., Rongvaux, A., Wang, L., Durand, C. M., Ghiaur, G., et al. (2015). Broad CTL response is required to clear latent HIV-1 due to dominance of escape mutations. Nature 517, 381-385. doi: 10.1038/nature14053

Descours, B., Petitjean, G., López-Zaragoza, J.-L., Bruel, T., Raffel, R., Psomas, C., et al. (2017). CD32a is a marker of a CD4 T-cell HIV reservoir harbouring replication-competent proviruses. Nature 543, 564-567. doi: 10.1038 /nature 21710

Désiré, N., Dehée, A., Schneider, V., Jacomet, C., Goujon, C., Girard, P. M., et al. (2001). Quantification of human immunodeficiency virus type 1 proviral load by a TaqMan real-time PCR assay. J. Clin. Microbiol. 39, 1303-1310. doi: 10.1128/JCM.39.4.1303-1310.2001

Di Mascio, M., Paik, C. H., Carrasquillo, J. A., Maeng, J.-S., Jang, B.-S., Shin, I. S., et al. (2009). Noninvasive in vivo imaging of CD4 cells in simianhuman immunodeficiency virus (SHIV)-infected nonhuman primates. Blood 114, 328-337. doi: 10.1182/blood-2008-12-192203

Dinoso, J. B., Kim, S. Y., Wiegand, A. M., Palmer, S. E., Gange, S. J., Cranmer, L. et al. (2009). Treatment intensification does not reduce residual HIV-1 viremia in patients on highly active antiretroviral therapy. Proc. Natl. Acad. Sci. U.S.A. 106, 9403-9408. doi: 10.1073/pnas.0903107106

Doyon, G., Zerbato, J., Mellors, J. W., and Sluis-Cremer, N. (2013). Disulfiram reactivates latent HIV-1 expression through depletion of the phosphatase and tensin homolog. AIDS 27, F7-F11. doi: 10.1097/QAD.0b013e32835 70620

Ebina, H., Misawa, N., Kanemura, Y., and Koyanagi, Y. (2013). Harnessing the CRISPR/Cas9 system to disrupt latent HIV-1 provirus. Sci. Rep. 3:2510. doi: $10.1038 /$ srep02510

Einkauf, K. B., Lee, G. Q., Gao, C., Sharaf, R., Sun, X., Hua, S., et al. (2019). Intact HIV-1 proviruses accumulate at distinct chromosomal positions during prolonged antiretroviral therapy. J. Clin. Invest. 129, 988-998. doi: 10.1172/JCI124291

Eisele, E., and Siliciano, R. F. (2012). Redefining the viral reservoirs that prevent HIV-1 eradication. Immunity 37, 377-388. doi: 10.1016/j.immuni.2012.08.010

Elliott, J. H., McMahon, J. H., Chang, C. C., Lee, S. A., Hartogensis, W., Bumpus, N., et al. (2015). Short-term administration of disulfiram for reversal of latent HIV infection: a phase 2 dose-escalation study. Lancet HIV 2, e520-e529. doi: 10.1016/S2352-3018(15)00226-X

Eriksson, S., Graf, E. H., Dahl, V., Strain, M. C., Yukl, S. A., Lysenko, E. S., et al. (2013). Comparative analysis of measures of viral reservoirs in HIV-1 eradication studies. PLoS Pathog. 9:e1003174. doi: 10.1371/journal.ppat.1003174

Evans, V. A., van der Sluis, R. M., Solomon, A., Dantanarayana, A., McNeil, C., Garsia, R., et al. (2018). Programmed cell death-1 contributes to the establishment and maintenance of HIV-1 latency. AIDS 32, 1491-1497. doi: 10.1097/QAD.0000000000001849

Falcinelli, S. D., Ceriani, C., Margolis, D. M., and Archin, N. M. (2019). New frontiers in measuring and characterizing the HIV reservoir. Front. Microbiol. 10:2878. doi: 10.3389/fmicb.2019.02878

Finzi, D., Blankson, J., Siliciano, J. D., Margolick, J. B., Chadwick, K., Pierson, T., et al. (1999). Latent infection of CD4+ T cells provides a mechanism for lifelong persistence of HIV-1, even in patients on effective combination therapy. Nat. Med. 5, 512-517. doi: 10.1038/8394

Finzi, D., Hermankova, M., Pierson, T., Carruth, L. M., Buck, C., Chaisson, R. E., et al. (1997). Identification of a reservoir for HIV-1 in patients on highly active antiretroviral therapy. Science 278, 1295-1300. doi: $10.1126 /$ science. 278.5341 .1295

Fletcher, C. V., Staskus, K., Wietgrefe, S. W., Rothenberger, M., Reilly, C., Chipman, J. G., et al. (2014). Persistent HIV-1 replication is associated with lower 
antiretroviral drug concentrations in lymphatic tissues. Proc. Natl. Acad. Sci. U.S.A. 111, 2307-2312. doi: 10.1073/pnas.1318249111

Frank, I., Acharya, A., Routhu, N. K., Aravantinou, M., Harper, J. L., Maldonado, S., et al. (2019). A Tat/Rev induced limiting dilution assay to measure viral reservoirs in non-human primate models of HIV infection. Sci. Rep. 9:12078. doi: 10.1038/s41598-019-48354-3

Fromentin, R., Bakeman, W., Lawani, M. B., Khoury, G., Hartogensis, W., DaFonseca, S., et al. (2016). CD4 + T cells expressing PD-1, TIGIT and LAG-3 contribute to HIV persistence during ART. PLoS Pathog. 12:e1005761. doi: 10.1371/journal.ppat.1005761

Fromentin, R., DaFonseca, S., Costiniuk, C. T., El-Far, M., Procopio, F. A., Hecht, F. M., et al. (2019). PD-1 blockade potentiates HIV latency reversal ex vivo in CD4+ T cells from ART-suppressed individuals. Nat. Commun. 10:814. doi: 10.1038/s41467-019-08798-7

Fukazawa, Y., Lum, R., Okoye, A. A., Park, H., Matsuda, K., Bae, J. Y., et al. (2015). B cell follicle sanctuary permits persistent productive simian immunodeficiency virus infection in elite controllers. Nat. Med. 21, 132-139. doi: 10.1038/nm.3781

Fun, A., Mok, H. P., Wills, M. R., and Lever, A. M. (2017). A highly reproducible quantitative viral outgrowth assay for the measurement of the replicationcompetent latent HIV-1 reservoir. Sci. Rep. 7:43231. doi: 10.1038/srep43231

Gaebler, C., Lorenzi, J. C. C., Oliveira, T. Y., Nogueira, L., Ramos, V., Lu, C.-L., et al. (2019). Combination of quadruplex qPCR and next-generation sequencing for qualitative and quantitative analysis of the HIV-1 latent reservoir. J. Exp. Med. 216, 2253-2264. doi: 10.1084/jem.20190896

Gandhi, R. T., Coombs, R. W., Chan, E. S., Bosch, R. J., Zheng, L., Margolis, D. M., et al. (2012). No effect of raltegravir intensification on viral replication markers in the blood of HIV-1-infected patients receiving antiretroviral therapy. $J$. Acquir. Immune Defic. Syndr. 59, 229-235. doi: 10.1097/QAI.0b013e31823fd1f2

Gandhi, R. T., Kwon, D. S., Macklin, E. A., Shopis, J. R., McLean, A. P., McBrine, N., et al. (2016). Immunization of HIV-1-infected persons with autologous dendritic cells transfected with mRNA encoding HIV-1 Gag and Nef: results of a randomized, placebo-controlled clinical Trial. JAIDS J. Acquir. Immune Defic. Syndr. 71, 246-53 doi: 10.1097/QAI.0000000000000852

Ganor, Y., Real, F., Sennepin, A., Dutertre, C.-A., Prevedel, L., Xu, L., et al. (2019). HIV-1 reservoirs in urethral macrophages of patients under suppressive antiretroviral therapy. Nat. Microbiol. 4, 633-644. doi: 10.1038/s41564-018-0335-Z

García, F., Climent, N., Assoumou, L., Gil, C., González, N., Alcam,í, J., et al. (2011). A therapeutic dendritic cell-based vaccine for HIV-1 infection. J. Infect. Dis. 203, 473-478. doi: 10.1093/infdis/jiq077

Gay, C. L., Bosch, R. J., Ritz, J., Hataye, J. M., Aga, E., Tressler, R. L., et al. (2017a). Clinical trial of the anti-PD-L1 antibody BMS-936559 in HIV-1 infected participants on suppressive antiretroviral therapy. J. Infect. Dis. 215, 1725-1733. doi: 10.1093/infdis/jix191

Gay, C. L., DeBenedette, M. A., Tcherepanova, I. Y., Gamble, A., Lewis, W. E., Cope, A. B., et al. (2017b). Immunogenicity of AGS-004 dendritic cell therapy in patients treated during Acute HIV infection. AIDS Res. Hum. Retroviruses 34, 111-122. doi: 10.1089/aid.2017.0071

Giacomet, V., Trabattoni, D., Zanchetta, N., Biasin, M., Gismondo, M., Clerici, M., et al. (2014). No cure of HIV infection in a child despite early treatment and apparent viral clearance. Lancet 384:1320. doi: 10.1016/S0140-6736(14)61405-7

Graf, E. H., Pace, M. J., Peterson, B. A., Lynch, L. J., Chukwulebe, S. B., Mexas, A. M., et al. (2013). Gag-positive reservoir cells are susceptible to HIV-specific cytotoxic T lymphocyte mediated clearance in vitro and can be detected in vivo. PLoS ONE 8:e71879. doi: 10.1371/journal.pone.0071879

Grau-Expósito, J., Luque-Ballesteros, L., Navarro, J., Curran, A., Burgos, J., Ribera, E., et al. (2019). Latency reversal agents affect differently the latent reservoir present in distinct CD4+ T subpopulations. PLoS Pathog. 15:e1007991. doi: 10.1371/journal.ppat.1007991

Grau-Expósito, J., Serra-Peinado, C., Miguel, L., Navarro, J., Curran, A., Burgos, J., et al. (2017). A novel single-cell FISH-flow assay identifies effector memory $\mathrm{CD} 4+\mathrm{T}$ cells as a major niche for HIV-1 transcription in HIV-infected patients. MBio 8, e00876-e00817. doi: 10.1128/mBio.00876-17

Gupta, R. K., Abdul-Jawad, S., McCoy, L. E., Mok, H. P., Peppa, D., Salgado, M., et al. (2019). HIV-1 remission following CCR5 $\Delta 32 / \Delta 32$ haematopoietic stemcell transplantation. Nature 568, 244-248. doi: 10.1038/s41586-019-1027-4
Hale, M., Mesojednik, T., Romano Ibarra, G. S., Sahni, J., Bernard, A., Sommer, K., et al. (2017). Engineering HIV-resistant, anti-HIV chimeric antigen receptor T cells. Mol. Ther. 25, 570-579. doi: 10.1016/j.ymthe.2016.12.023

Hatano, H., Strain, M. C., Scherzer, R., Bacchetti, P., Wentworth, D., Hoh, R., et al. (2013). Increase in 2-long terminal repeat circles and decrease in D-dimer after raltegravir intensification in patients with treated HIV infection: a randomized, placebo-controlled trial. J. Infect. Dis. 208, 1436-1442. doi: 10.1093/infdis/jit453

Henrich, T. J., Gallien, S., Li, J. Z., Pereyra, F., and Kuritzkes, D. R. (2012). Low-level detection and quantitation of cellular HIV-1 DNA and 2-LTR circles using droplet digital PCR. J. Virol. Methods 186, 68-72. doi: 10.1016/j.jviromet.2012.08.019

Henrich, T. J., Hatano, H., Bacon, O., Hogan, L. E., Rutishauser, R., Hill, A., et al. (2017). HIV-1 persistence following extremely early initiation of antiretroviral therapy (ART) during acute HIV-1 infection: an observational study. PLoS Med. 14:e1002417. doi: 10.1371/journal.pmed.1002417

Hermankova, M., Siliciano, J. D. D., Zhou, Y., Monie, D., Chadwick, K., Margolick, J. B. B., et al. (2003). Analysis of human immunodeficiency virus type 1 gene expression in latently infected resting CD4+ T lymphocytes in vivo. J. Virol. 77, 7383-7392. doi: 10.1128/JVI.77.13.7383-7392.2003

Hiener, B., Horsburgh, B. A., Eden, J.-S., Barton, K., Schlub, T. E., Lee, E., et al. (2017). Identification of genetically intact HIV-1 proviruses in specific CD4+ T cells from effectively treated participants. Cell Rep. 21, 813-822. doi: 10.1016/j.celrep.2017.09.081

Hindson, B. J., Ness, K. D., Masquelier, D. A., Belgrader, P., Heredia, N. J., Makarewicz, A. J., et al. (2011). High-throughput droplet digital PCR system for absolute quantitation of DNA copy number. Anal. Chem. 83, 8604-8610. doi: $10.1021 / \mathrm{ac} 202028 \mathrm{~g}$

Ho, Y. C., Shan, L., Hosmane, N. N., Wang, J., Laskey, S. B., Rosenbloom, D. I. S., et al. (2013). Replication-competent noninduced proviruses in the latent reservoir increase barrier to HIV-1 cure. Cell 155, 540-551. doi: 10.1016/j.cell.2013.09.020

Hosmane, N. N., Kwon, K. J., Bruner, K. M., Capoferri, A. A., Beg, S., Rosenbloom, D. I. S., et al. (2017). Proliferation of latently infected CD4+ T cells carrying replication-competent HIV-1: potential role in latent reservoir dynamics. $J$. Exp. Med. 214, 959-972. doi: 10.1084/jem.20170193

Hu, W., Kaminski, R., Yang, F., Zhang, Y., Cosentino, L., Li, F., et al. (2014). RNA-directed gene editing specifically eradicates latent and prevents new HIV-1 infection. Proc. Natl. Acad. Sci. U.S.A. 111, 11461-11466. doi: $10.1073 /$ pnas.1405186111

Hutter, G., Nowak, D., Mossner, M., Ganepola, S., Müß, A., Allers, K., et al. (2009). Long-term control of HIV by CCR5 delta32/delta32 stem-cell transplantation. N. Engl. J. Med. 360, 692-698. doi: 10.1056/NEJMoa0802905

Imamichia, H., Dewar, R. L., Adelsberger, J. W., Rehm, C. A., O'doherty, U., Paxinos, E. E., et al. (2016). Defective HIV-1 proviruses produce novel proteincoding RNA species in HIV-infected patients on combination antiretroviral therapy. Proc. Natl. Acad. Sci. U.S.A. 113, 8783-8788. doi: $10.1073 /$ pnas. 1609057113

Jiang, G., Mendes, E. A., Kaiser, P., Wong, D. P., Tang, Y., Cai, I., et al. (2015). Synergistic reactivation of latent HIV expression by ingenol-3-angelate, PEP005, targeted NF-kB signaling in combination with JQ1 induced $\mathrm{p}-\mathrm{TEFb}$ activation. PLoS Pathog. 11:e1005066. doi: 10.1371/journal.ppat.1005066

Jones, R. B., O’Connor, R., Mueller, S., Foley, M., Szeto, G. L., Karel, D., et al. (2014). Histone deacetylase inhibitors impair the elimination of HIV-infected cells by cytotoxic T-lymphocytes. PLoS Pathog. 10:e1004287. doi: 10.1371/journal.ppat.1004287

Josefsson, L., von Stockenstrom, S., Faria, N. R., Sinclair, E., Bacchetti, P., Killian, M., et al. (2013). The HIV-1 reservoir in eight patients on long-term suppressive antiretroviral therapy is stable with few genetic changes over time. Proc. Natl. Acad. Sci. U.S.A. 110, E4987-E4996. doi: 10.1073/pnas.1308313110

Kabamba-Mukadi, B., Henrivaux, P., Ruelle, J., Delferrière, N., Bodéus, M., and Goubau, P. (2005). Human immunodeficiency virus type 1 (HIV-1) proviral DNA load in purified CD4+ cells by lightcycler $®$ real-time PCR. BMC Infect. Dis. 5:15. doi: 10.1186/1471-2334-5-15

Kaminski, R., Bella, R., Yin, C., Otte, J., Ferrante, P., Gendelman, H. E., et al. (2016). Excision of HIV-1 DNA by gene editing: a proof-of-concept in vivo study. Gene Ther. 23, 690-695. doi: 10.1038/gt.2016.41 
Kearney, M. F., Wiegand, A., Shao, W., McManus, W. R., Bale, M. J., Luke, B., et al. (2017). Ongoing HIV replication during ART reconsidered. Open Forum Infect. Dis. 4:ofx173. doi: 10.1093/ofid/ofx173

Kimberland, M. L., Hou, W., Alfonso-Pecchio, A., Wilson, S., Rao, Y., Zhang, S., et al. (2018). Strategies for controlling CRISPR/Cas9 off-target effects and biological variations in mammalian genome editing experiments. J. Biotechnol. 284, 91-101. doi: 10.1016/j.jbiotec.2018.08.007

Kinoshita, S., Chen, B. K., Kaneshima, H., and Nolan, G. P. (1998). Host control of HIV-1 parasitism in T cells by the nuclear factor of activated T cells. Cell 95, 595-604. doi: 10.1016/S0092-8674(00)81630-X

Kiselinova, M., de Spiegelaere, W., Buzon, M. J., Malatinkova, E., Lichterfeld, M., and Vandekerckhove, L. (2016). Integrated and total HIV-1 DNA predict ex vivo viral outgrowth. PLoS Pathog. 12:e1005472. doi: 10.1371/journal.ppat.1005472

Kiselinova, M., Pasternak, A. O., de Spiegelaere, W., Vogelaers, D., Berkhout, B., and Vandekerckhove, L. (2014). Comparison of droplet digital PCR and seminested real-time PCR for quantification of cell-associated HIV-1 RNA. PLoS ONE 9:e85999. doi: 10.1371/journal.pone.0085999

Knights, H. D. J. (2017). A critical review of the evidence concerning the HIV latency reversing effect of disulfiram, the possible explanations for its inability to reduce the size of the latent reservoir in vivo, and the caveats associated with its use in practice. AIDS Res. Treat. 2017:8239428. doi: 10.1155/2017/8239428

Kondo, M., Sudo, K., Tanaka, R., Sano, T., Sagara, H., Iwamuro, S., et al. (2009). Quantitation of HIV-1 group M proviral DNA using TaqMan MGB real-time PCR. J. Virol. Methods 157, 141-146. doi: 10.1016/j.jviromet.2008.12.006

Kostrikis, L. G., Touloumi, G., Karanicolas, R., Pantazis, N., Anastassopoulou, C., Karafoulidou, A., et al. (2002). Quantitation of human immunodeficiency virus type 1 DNA forms with the second template switch in peripheral blood cells predicts disease progression independently of plasma RNA load. J. Virol. 76, 10099-10108. doi: 10.1128/JVI.76.20.10099-10108.2002

Kulpa, D. A., and Chomont, N. (2015). HIV persistence in the setting of antiretroviral therapy: when, where and how does HIV hide? J. Virus Erad. 1, 59-66.

Kwon, K. J., Timmons, A. E., Sengupta, S., Simonetti, F. R., Zhang, H., Hoh, R., et al. (2020). Different human resting memory CD4+ T cell subsets show similar low inducibility of latent HIV-1 proviruses. Sci. Transl. Med. 12:eaax6795. doi: 10.1126/scitranslmed.aax6795

Lada, S. M., Huang, K., VanBelzen, D. J., Montaner, L. J., O'Doherty, U., and Richman, D. D. (2018). Quantitation of integrated HIV provirus by pulsedfield gel electrophoresis and droplet digital PCR. J. Clin. Microbiol. 56:e01158e01118. doi: 10.1128/JCM.01158-18

Lafeuillade, A., Poggi, C., Chadapaud, S., Hittinger, G., Chouraqui, M., Pisapia, M., et al. (2001). Pilot study of a combination of highly active antiretroviral therapy and cytokines to induce HIV-1 remission. J. Acquir. Immune Defic. Syndr. 26, 44-55. doi: 10.1097/00126334-200101010-00006

Laird, G. M., Eisele, E. E., Rabi, S. A., Lai, J., Chioma, S., Blankson, J. N., et al. (2013). Rapid quantification of the latent reservoir for HIV-1 using a viral outgrowth assay. PLoS Pathog. 9:e1003398. doi: 10.1371/journal.ppat.1003398

Lambrechts, L., Cole, B., Rutsaert, S., Trypsteen, W., and Vandekerckhove, L. (2020). Emerging PCR-based techniques to study HIV-1 reservoir persistence. Viruses 12:149. doi: 10.3390/v12020149

Lassen, K. G., Hebbeler, A. M., Bhattacharyya, D., Lobritz, M. A., and Greene, W. C. (2012). A flexible model of HIV-1 latency permitting evaluation of many primary CD4 T-cell reservoirs. PLoS ONE 7:e30176. doi: 10.1371 /journal.pone.0030176

Lebbink, R. J., de Jong, D. C. M., Wolters, F., Kruse, E. M., van Ham, P. M., Wiertz, E. J. H. J., et al. (2017). A combinational CRISPR/Cas9 gene-editing approach can halt HIV replication and prevent viral escape. Sci. Rep. 7:41968. doi: $10.1038 /$ srep41968

Lee, G. Q., Orlova-Fink, N., Einkauf, K., Chowdhury, F. Z., Sun, X., Harrington, S., et al. (2017). Clonal expansion of genome-intact HIV-1 in functionally polarized Th1 CD4+ T cells. J. Clin. Invest. 127, 2689-2696. doi: 10.1172/JCI93289

Lehrman, G., Hogue, I. B., Palmer, S., Jennings, C., Spina, C. A., Wiegand, A., et al. (2005). Depletion of latent HIV-1 infection in vivo: a proof-of-concept study. Lancet 366, 549-555. doi: 10.1016/S0140-6736(05)67098-5

Leth, S., Schleimann, M. H., Nissen, S. K., Højen, J. F., Olesen, R., Graversen, M. E., et al. (2016). Combined effect of Vacc-4x, recombinant human granulocyte macrophage colony-stimulating factor vaccination, and romidepsin on the
HIV-1 reservoir (REDUC): a single-arm, phase 1B/2A trial. Lancet HIV 3, e463-e472. doi: 10.1016/S2352-3018(16)30055-8

Lévy, Y., Durier, C., Lascaux, A.-S., Meiffrédy, V., Gahéry-Ségard, H., Goujard, C., et al. (2006). Sustained control of viremia following therapeutic immunization in chronically HIV-1-infected individuals. AIDS 20, 405-413. doi: 10.1097/01.aids.0000206504.09159.d3

Lévy, Y., Gahéry-Ségard, H., Durier, C., Lascaux, A.-S., Goujard, C., Meiffrédy, V., et al. (2005). Immunological and virological efficacy of a therapeutic immunization combined with interleukin-2 in chronically HIV-1 infected patients. AIDS 19, 279-286.

Li, P., Ruel, T., Fujimoto, K., Hatano, H., Yukl, S., Eller, L. A., et al. (2010). Novel application of locked nucleic acid chemistry for a Taqman assay for measuring diverse human immunodeficiency virus type 1 subtypes. J. Virol. Methods 170, 115-120. doi: 10.1016/j.jviromet.2010.09.011

Liao, H.-K., Gu, Y., Diaz, A., Marlett, J., Takahashi, Y., Li, M., et al. (2015). Use of the CRISPR/Cas9 system as an intracellular defense against HIV-1 infection in human cells. Nat. Commun. 6:6413. doi: 10.1038/ncomms7413

Lim, S.-Y., Osuna, C. E., Hraber, P. T., Hesselgesser, J., Gerold, J. M., Barnes, T. L., et al. (2018). TLR7 agonists induce transient viremia and reduce the viral reservoir in SIV-infected rhesus macaques on antiretroviral therapy. Sci. Transl. Med. 10:eaao4521. doi: 10.1126/scitranslmed.aao4521

Liszewski, M. K., Yu, J. J., and O’Doherty, U. (2009). Detecting HIV1 integration by repetitive-sampling Alu-gag PCR. Methods 47, 254-260. doi: 10.1016/j.ymeth.2009.01.002

Liu, J., Perkins, N. D., Schmid, R. M., and Nabel, G. J. (1992). Specific NF-kappa B subunits act in concert with Tat to stimulate human immunodeficiency virus type 1 transcription. J. Virol. 66, 3883-3887. doi: 10.1128/JVI.66.6.3883-3887.1992

Liu, L., Patel, B., Ghanem, M. H., Bundoc, V., Zheng, Z., Morgan, R. A., et al. (2015). Novel CD4-based bispecific chimeric antigen receptor designed for enhanced anti-HIV potency and absence of HIV entry receptor activity. J. Virol. 89, 6685-6694. doi: 10.1128/JVI.00474-15

Liu, R., Paxton, W. A., Choe, S., Ceradini, D., Martin, S. R., Horuk, R., et al. (1996). Homozygous defect in HIV-1 coreceptor accounts for resistance of some multiply-exposed individuals to HIV-1 infection. Cell 86, 367-377. doi: 10.1016/S0092-8674(00)80110-5

López-Huertas, M. R., Jiménez-Tormo, L., Madrid-Elena, N., Gutiérrez, C., Rodríguez-Mora, S., Coiras, M., et al. (2017). The CCR5-antagonist maraviroc reverses HIV-1 latency in vitro alone or in combination with the PKC-agonist Bryostatin-1. Sci. Rep. 7:2385. doi: 10.1038/s41598-017-02634-y

Lorenzi, J. C. C., Cohen, Y. Z., Cohn, L. B., Kreider, E. F., Barton, J. P., Learn, G. H., et al. (2016). Paired quantitative and qualitative assessment of the replicationcompetent HIV-1 reservoir and comparison with integrated proviral DNA. Proc. Natl. Acad. Sci. U.S.A. 113, E7908-E7916. doi: 10.1073/pnas.1617789113

Lorenzo-Redondo, R., Fryer, H. R., Bedford, T., Kim, E.-Y., Archer, J., Kosakovsky Pond, S. L., et al. (2016). Persistent HIV-1 replication maintains the tissue reservoir during therapy. Nature 530, 51-56. doi: 10.1038/nature16933

Macedo, A. B., Novis, C. L., de Assis, C. M., Sorensen, E. S., Moszczynski, P., Huang, S., et al. (2018). Dual TLR2 and TLR7 agonists as HIV latency-reversing agents. JCI Insight 3:e122673. doi: 10.1172/jci.insight.122673

Madrid-Elena, N., García-Bermejo, M. L., Serrano-Villar, S., Díaz-de Santiago, A., Sastre, B., Gutiérrez, C., et al. (2018). Maraviroc Is associated with latent HIV-1 reactivation through NF- $\mathrm{B}$ activation in resting CD4+ $\mathrm{T}$ cells from HIVinfected individuals on suppressive antiretroviral therapy. J. Virol. 92:e0193117. doi: 10.1128/JVI.01931-17

Malatinkova, E., de Spiegelaere, W., Bonczkowski, P., Kiselinova, M., Vervisch, K., Trypsteen, W., et al. (2015). Impact of a decade of successful antiretroviral therapy initiated at HIV-1 seroconversion on blood and rectal reservoirs. Elife 4:e09115. doi: 10.7554/eLife.09115

Maldarelli, F., Wu, X., Su, L., Simonetti, F. R., Shao, W., Hill, S., et al. (2014). Specific HIV integration sites are linked to clonal expansion and persistence of infected cells. Science 345, 179-183. doi: 10.1126/science.1254194

Marsden, M. D., Wu, X., Navab, S. M., Loy, B. A., Schrier, A. J., DeChristopher, B. A., et al. (2018). Characterization of designed, synthetically accessible bryostatin analog HIV latency reversing agents. Virology 520, 83-93. doi: 10.1016/j.virol.2018.05.006

Martin, G. E., Pace, M., Thornhill, J. P., Phetsouphanh, C., Meyerowitz, J., Gossez, M., et al. (2018). CD32-expressing CD4 T cells are phenotypically 
diverse and can contain proviral HIV DNA. Front. Immunol. 9:928. doi: 10.3389/fimmu.2018.00928

Martrus, G., Niehrs, A., Cornelis, R., Rechtien, A., García-Beltran, W., Lütgehetmann, M., et al. (2016). Kinetics of HIV-1 latency reversal quantified on the single-cell level using a novel flow-based technique. J. Virol. 90, 9018-9028. doi: 10.1128/JVI.01448-16

Massanella, M., and Richman, D. D. (2016). Measuring the latent reservoir in vivo. J. Clin. Invest. 126, 464-472. doi: 10.1172/JCI80567

Massanella, M., Yek, C., Lada, S. M., Nakazawa, M., Shefa, N., Huang, K., et al. (2018). Improved assays to measure and characterize the inducible HIV reservoir. EBiomedicine 36, 113-121. doi: 10.1016/j.ebiom.2018.09.036

McBrien, J. B., Mavigner, M., Franchitti, L., Smith, S. A., White, E., Tharp, G. K., et al. (2020). Robust and persistent reactivation of SIV and HIV by N-803 and depletion of CD8+ cells. Nature 578, 154-159. doi: 10.1038/s41586-020-1946-0

McGary, C. S., Deleage, C., Harper, J., Micci, L., Ribeiro, S. P., Paganini, S., et al. (2017). CTLA-4+PD-1- memory CD4+ T cells critically contribute to viral persistence in antiretroviral therapy-suppressed, siv-infected rhesus macaques. Immunity 47, 776-788.e5. doi: 10.1016/j.immuni.2017.09.018

McMahon, D., Jones, J., Wiegand, A., Gange, S. J., Kearney, M., Palmer, S., et al. (2010). Short-course Raltegravir intensification does not reduce persistent lowlevel viremia in patients with HIV-1 suppression during receipt of combination antiretroviral therapy. Clin. Infect. Dis. 50, 912-919. doi: 10.1086/650749

McManamy, M. E. M., Hakre, S., Verdin, E. M., and Margolis, D. M. (2014). Therapy for latent HIV-1 infection: the role of histone deacetylase inhibitors. Antivir. Chem. Chemother. 23, 145-149. doi: 10.3851/IMP2551

Méndez, C., Ledger, S., Petoumenos, K., Ahlenstiel, C., and Kelleher, A. D. (2018). RNA-induced epigenetic silencing inhibits HIV-1 reactivation from latency. Retrovirology 15:67. doi: 10.1186/s12977-018-0451-0

Metcalf Pate, K. A., Pohlmeyer, C. W., Walker-Sperling, V. E., Foote, J. B., Najarro, K. M., Cryer, C. G., et al. (2015). A murine viral outgrowth assay to detect residual HIV type 1 in patients with undetectable viral loads. J. Infect. Dis. 212, 1387-1396. doi: 10.1093/infdis/jiv230

Mexas, A. M., Graf, E. H., Pace, M. J., Yu, J. J., Papasavvas, E., Azzoni, L., et al. (2012). Concurrent measures of total and integrated HIV DNA monitor reservoirs and ongoing replication in eradication trials. AIDS 26, 2295-2306. doi: 10.1097/QAD.0b013e32835a5c2f

Mousseau, G., Kessing, C. F., Fromentin, R., Trautmann, L., Chomont, N., and Valente, S. T. (2015). The tat inhibitor didehydro-cortistatin a prevents HIV-1 reactivation from latency. MBio 6:e00465-e00415. doi: 10.1128/mBio.00465-15

Munir, S., Thierry, S., Subra, F., Deprez, E., and Delelis, O. (2013). Quantitative analysis of the time-course of viral DNA forms during the HIV-1 life cycle. Retrovirology 10:87. doi: 10.1186/1742-4690-10-87

Mylvaganam, G. H., Silvestri, G., and Amara, R. R. (2015). HIV therapeutic vaccines: moving towards a functional cure. Curr. Opin. Immunol. 35, 1-8. doi: 10.1016/j.coi.2015.05.001

Nixon, C. C., Mavigner, M., Sampey, G. C., Brooks, A. D., Spagnuolo, R. A., Irlbeck, D. M., et al. (2020). Systemic HIV and SIV latency reversal via non-canonical NF-kB signalling in vivo. Nature. 578, 160-165. doi: 10.1038/s41586-020-1951-3

Nolan, D. J., Rose, R., Rodriguez, P. H., Salemi, M., Singer, E. J., Lamers, S. L., et al. (2017). The spleen is an HIV-1 sanctuary during combined antiretroviral therapy. AIDS Res. Hum. Retroviruses 34, 123-125. doi: 10.1089/aid.2017.0254

Novis, C. L., Archin, N. M., Buzon, M. J., Verdin, E., Round, J. L., Lichterfeld, M., et al. (2013). Reactivation of latent HIV-1 in central memory CD4+T cells through TLR-1/2 stimulation. Retrovirology 10, 119. doi: 10.1186/1742-4690-10-119

O'Doherty, U., Swiggard, W. J., Jeyakumar, D., McGain, D., and Malim, M. H. (2002). A sensitive, quantitative assay for human immunodeficiency virus Type 1 integration. J. Virol. 76, 10942-10950. doi: 10.1128/JVI.76.21.10942-10950.2002

Ophinni, Y., Inoue, M., Kotaki, T., and Kameoka, M. (2018). CRISPR/Cas9 system targeting regulatory genes of HIV-1 inhibits viral replication in infected T-cell cultures. Sci. Rep. 8:7784. doi: 10.1038/s41598-018-2 6190-1

Osuna, C. E., Lim, S.-Y., Kublin, J. L., Apps, R., Chen, E., Mota, T. M., et al. (2018). Evidence that CD32a does not mark the HIV-1 latent reservoir. Nature 561, E20-E28. doi: 10.1038/s41586-018-0495-2
Pankrac, J., Klein, K., and Mann, J. F. S. (2017). Eradication of HIV-1 latent reservoirs through therapeutic vaccination. AIDS Res. Ther. 14:45. doi: 10.1186/s12981-017-0177-4

Pantaleo, G., and Levy, Y. (2016). Therapeutic vaccines and immunological intervention in HIV infection: a paradigm change. Curr. Opin. HIV AIDS 11, 576-584. doi: 10.1097/COH.0000000000000324

Pardons, M., Baxter, A. E., Massanella, M., Pagliuzza, A., Fromentin, R., Dufour, C., et al. (2019a). Single-cell characterization and quantification of translationcompetent viral reservoirs in treated and untreated HIV infection. PLoS Pathog. 15:e1007619. doi: 10.1371/journal.ppat.1007619

Pardons, M., Fromentin, R., Pagliuzza, A., Routy, J.-P., and Chomont, N. (2019b). Latency-Reversing agents induce differential responses in distinct memory CD4 T cell subsets in individuals on antiretroviral therapy. Cell Rep. 29, 2783-2795.e5. doi: 10.1016/j.celrep.2019.10.101

Passaes, C. P. B., Bruel, T., Decalf, J., David, A., Angin, M., Monceaux, V., et al. (2017). Ultrasensitive HIV-1 p24 assay detects single infected cells and differences in reservoir induction by latency reversal agents. J. Virol. 91, e02296-e02216. doi: 10.1128/JVI.02296-16

Pasternak, A. O., and Berkhout, B. (2018). What do we measure when we measure cell-associated HIV RNA. Retrovirology 15:13. doi: 10.1186/s12977-018-0397-2

Pasternak, A. O., de Bruin, M., Jurriaans, S., Bakker, M., Berkhout, B., Prins, J. M., et al. (2012). Modest nonadherence to antiretroviral therapy promotes residual HIV-1 replication in the absence of virological rebound in plasma. J. Infect. Dis. 206, 1443-1452. doi: 10.1093/infdis/jis502

Pasternak, A. O., Jurriaans, S., Bakker, M., Prins, J. M., Berkhout, B., and Lukashov, V. V. (2009). Cellular levels of HIV unspliced RNA from patients on combination antiretroviral therapy with undetectable plasma viremia predict the therapy outcome. PLoS ONE 4:e8490. doi: 10.1371/journal.pone.0008490

Perelson, A. S., Essunger, P., Cao, Y., Vesanen, M., Hurley, A., Saksela, K., et al. (1997). Decay characteristics of HIV-1-infected compartments during combination therapy. Nature 387, 188-191. doi: 10.1038/387188a0

Pérez, L., Anderson, J., Chipman, J., Thorkelson, A., Chun, T.-W., Moir, S. et al. (2018). Conflicting evidence for HIV enrichment in CD32+ CD4 T cells. Nature 561, E9-E16. doi: 10.1038/s41586-018-0493-4

Perez, M., de Vinuesa, A. G., Sanchez-Duffhues, G., Marquez, N., Bellido, M. L., Munoz-Fernandez, M. A., et al. (2010). Bryostatin-1 synergizes with histone deacetylase inhibitors to reactivate HIV-1 from latency. Curr. HIV Res. 8, 418-429. doi: 10.2174/157016210793499312

Persaud, D., Gay, H., Ziemniak, C., Chen, Y. H., Piatak, M. Jr., Chun, T.-W., et al. (2013). Absence of detectable HIV-1 viremia after treatment cessation in an infant. N. Engl. J. Med. 369, 1828-1835. doi: 10.1056/NEJMoa1302976

Pierson, T., Hoffman, T. L., Blankson, J., Finzi, D., Chadwick, K., Margolick, J. B., et al. (2000). Characterization of chemokine receptor utilization of viruses in the latent reservoir for human immunodeficiency virus Type 1. J. Virol. 74, 7824-7833. doi: 10.1128/JVI.74.17.7824-7833.2000

Pierson, T. C., Kieffer, T. L., Ruff, C. T., Buck, C., Gange, S. J., and Siliciano, R. F. (2002). Intrinsic stability of episomal circles formed during human immunodeficiency virus type 1 replication. J. Virol. 76, 4138-4144. doi: 10.1128/JVI.76.8.4138-4144.2002

Plesa, G., Dai, J., Baytop, C., Riley, J. L., June, C. H., and O’Doherty, U. (2007) Addition of deoxynucleosides enhances human immunodeficiency virus type 1 integration and 2LTR formation in resting CD4+ T cells. J. Virol. 81, 13938-13942. doi: 10.1128/JVI.01745-07

Pollard, R. B., Rockstroh, J. K., Pantaleo, G., Asmuth, D. M., Peters, B., Lazzarin, A., et al. (2014). Safety and efficacy of the peptide-based therapeutic vaccine for HIV-1, Vacc- $4 \times$ : a phase 2 randomised, double-blind, placebo-controlled trial. Lancet Infect. Dis. 14, 291-300. doi: 10.1016/S1473-3099(13)70343-8

Prins, J. M., Jurriaans, S., van Praag, R. M. E., Blaak, H., van Rij, R., Schellekens, P. T. A., et al. (1999). Immuno-activation with anti-CD3 and recombinant human IL-2 in HIV-1-infected patients on potent antiretroviral therapy. AIDS 13, 2405-2410. doi: 10.1097/00002030-199912030-00012

Procopio, F. A., Fromentin, R., Kulpa, D. A., Brehm, J. H., Bebin, A. G., Strain, M. C., et al. (2015). A novel assay to measure the magnitude of the inducible viral reservoir in HIV-infected individuals. EBiomedicine 2, 874-883. doi: 10.1016/j.ebiom.2015.06.019

Puertas, M. C., Gómez-Mora, E., Santos, J. R., Moltó, J., Urrea, V., Morón-López, S., et al. (2018). Impact of intensification with raltegravir on HIV-1-infected 
individuals receiving monotherapy with boosted PIs. J. Antimicrob. Chemother. 73, 1940-1948. doi: 10.1093/jac/dky106

Puray-Chavez, M., Tedbury, P. R., Huber, A. D., Ukah, O. B., Yapo, V., Liu, D., et al. (2017). Multiplex single-cell visualization of nucleic acids and protein during HIV infection. Nat. Commun. 8:1882. doi: 10.1038/s41467-017-0 1693-z

Rosenbloom, D. I. S., Bacchetti, P., Stone, M., Deng, X., Bosch, R. J., Richman, D. D., et al. (2019). Assessing intra-lab precision and inter-lab repeatability of outgrowth assays of HIV-1 latent reservoir size. PLoS Comput. Biol. 15:e1006849. doi: 10.1371/journal.pcbi.1006849

Rosenbloom, D. I. S., Elliott, O., Hill, A. L., Henrich, T. J., Siliciano, J. M., and Siliciano, R. F. (2015). Designing and interpreting limiting dilution assays: general principles and applications to the latent reservoir for human immunodeficiency virus-1. Open Forum Infect. Dis. 2:ofv123. doi: 10.1093/ofid/ofv123

Rosenbloom, D. I. S., Hill, A. L., Laskey, S. B., and Siliciano, R. F. (2017). Re-evaluating evolution in the HIV reservoir. Nature 551, E6-E9. doi: 10.1038 /nature24634

Rouzioux, C., and Avettand-Fenoël, V. (2018). Total HIV DNA: a global marker of HIV persistence. Retrovirology 15:30. doi: 10.1186/s12977-018-0412-7

Rouzioux, C., Mélard, A., and Avéttand-Fénoël, V. (2014). "Quantification of total HIV1-DNA in peripheral blood mononuclear cells," in Methods in Molecular Biology, eds E. Vicenzi and G. Poli (Totowa, NJ: Humana Press), 261-270. doi: 10.1007/978-1-62703-670-2_21

Ruggiero, A., Malatinkova, E., Rutsaert, S., Paxton, W. A., Vandekerckhove, L., and de Spiegelaere, W. (2017). Utility of integrated HIV-1 DNA quantification in cure studies. Future Virol. 12, 215-225. doi: 10.2217/fvl-20 16-0130

Rutsaert, S., Bosman, K., Trypsteen, W., Nijhuis, M., and Vandekerckhove, L. (2018a). Digital PCR as a tool to measure HIV persistence. Retrovirology 15:16. doi: 10.1186/s12977-018-0399-0

Rutsaert, S., De Spiegelaere, W., Van Hecke, C., De Scheerder, M.-A., Kiselinova, M., Vervisch, K., et al. (2018b). In-depth validation of total HIV-1 DNA assays for quantification of various HIV-1 subtypes. Sci. Rep. 8:17274. doi: 10.1038/s41598-018-35403-6

Sahu, G. K., Sango, K., Selliah, N., Ma, Q., Skowron, G., and Junghans, R. P. (2013). Anti-HIV designer T cells progressively eradicate a latently infected cell line by sequentially inducing HIV reactivation then killing the newly gp120-positive cells. Virology 446, 268-275. doi: 10.1016/j.virol.2013.08.002

Sanchez, G., Xu, X., Chermann, J. C., and Hirsch, I. (1997). Accumulation of defective viral genomes in peripheral blood mononuclear cells of human immunodeficiency virus type 1-infected individuals. J. Virol. 71, 2233-2240. doi: 10.1128/JVI.71.3.2233-2240.1997

Schmid, A., Gianella, S., von Wyl, V., Metzner, K. J., Scherrer, A. U., Niederöst, B., et al. (2010). Profound depletion of HIV-1 transcription in patients initiating antiretroviral therapy during acute infection. PLOS ONE 5:e13310. doi: 10.1371/journal.pone.0013310

Schooley, R. T., Spritzler, J., Wang, H., Lederman, M. M., Havlir, D., Kuritzkes, D. R., et al. (2010). AIDS clinical trials group 5197: a placebo-controlled trial of immunization of HIV-1-infected persons with a replication-deficient adenovirus Type 5 vaccine expressing the HIV-1 core protein. J. Infect. Dis. 202, 705-716. doi: $10.1086 / 655468$

Sengupta, S., and Siliciano, R. F. (2018). Targeting the Latent Reservoir for HIV-1. Immunity 48, 872-895. doi: 10.1016/j.immuni.2018. 04.030

Sgadari, C., Monini, P., Tripiciano, A., Picconi, O., Casabianca, A., Orlandi, C., et al. (2019). Continued decay of HIV proviral DNA upon vaccination with HIV-1 Tat of subjects on long-term ART: an 8-year follow-up study. Front. Immunol. 10:233. doi: 10.3389/fimmu.2019. 00233

Shan, L., Deng, K., Shroff, N. S., Durand, C. M., Rabi, S. A., Yang, H.-C., et al. (2012). Stimulation of HIV-1-specific cytolytic T lymphocytes facilitates elimination of latent viral reservoir after virus reactivation. Immunity 36, 491-501. doi: 10.1016/j.immuni.2012.01.014

Shan, L., Rabi, S. A., Laird, G. M., Eisele, E. E., Zhang, H., Margolick, J. B., et al. (2013). A novel PCR assay for quantification of HIV-1 RNA. J. Virol. 87, 6521-6525. doi: 10.1128/JVI.00006-13
Siliciano, J. D., Kajdas, J., Finzi, D., Quinn, T. C., Chadwick, K., Margolick, J. B., et al. (2003). Long-term follow-up studies confirm the stability of the latent reservoir for HIV-1 in resting CD4 + T cells. Nat. Med. 9, 727-728. doi: $10.1038 / \mathrm{nm} 880$

Siliciano, J. D., and Siliciano, R. F. (2005). Enhanced culture assay for detection and quantitation of latently infected, resting $\mathrm{CD} 4+\mathrm{T}$-cells carrying replicationcompetent virus in HIV-1-infected individuals. Methods Mol. Biol. 304, 3-15. doi: 10.1385/1-59259-907-9:003

Siliciano, R. F., and Greene, W. C. (2011). HIV latency. Cold Spring Harb. Perspect. Med. 1:a007096. doi: 10.1101/cshperspect.a007096

Simonetti, F. R., Sobolewski, M. D., Fyne, E., Shao, W., Spindler, J., Hattori, J., et al. (2016). Clonally expanded CD4+ T cells can produce infectious HIV-1 in vivo. Proc. Natl. Acad. Sci. U.S.A. 113, 1883-1888. doi: 10.1073/pnas.1522675113

Sloan, R. D., and Wainberg, M. A. (2011). The role of unintegrated DNA in HIV infection. Retrovirology 8:52. doi: 10.1186/1742-4690-8-52

Soriano-Sarabia, N., Bateson, R. E., Dahl, N. P., Crooks, A. M., Kuruc, J. D., Margolis, D. M., et al. (2014). Quantitation of replication-competent HIV-1 in populations of resting CD4+ T cells. J. Virol. 88, 14070-14077. doi: 10.1128/JVI.01900-14

Strain, M. C., Lada, S. M., Luong, T., Rought, S. E., Gianella, S., Terry, V. H., et al. (2013). Highly precise measurement of HIV DNA by droplet digital PCR. PLoS ONE 8:e55943. doi: 10.1371/journal.pone.0055943

Sun, H., Kim, D., Li, X., Kiselinova, M., Ouyang, Z., Vandekerckhove, L., et al. (2015). Th1/17 Polarization of CD4 T cells supports HIV-1 persistence during antiretroviral therapy. J. Virol. 89, 11284-11293. doi: 10.1128/JVI.01595-15

Sung, J. A., Patel, S., Clohosey, M. L., Roesch, L., Tripic, T., Kuruc, J. D., et al. (2018). HIV-specific, ex vivo expanded T cell therapy: feasibility, safety, and efficacy in ART-suppressed HIV-infected individuals. Mol. Ther. 26, 2496-2506. doi: 10.1016/j.ymthe.2018.08.015

Sunshine, S., Kirchner, R., Amr, S. S., Mansur, L., Shakhbatyan, R., Kim, M., et al. (2016). HIV integration site analysis of cellular models of HIV latency with a probe-enriched next-generation sequencing assay. J. Virol. 90, 4511-4519. doi: 10.1128/JVI.01617-15

Suzuki, K., Juelich, T., Lim, H., Ishida, T., Watanebe, T., Cooper, D. A., et al. (2008). Closed chromatin architecture is induced by an RNA duplex targeting the HIV-1 promoter region. J. Biol. Chem. 283, 23353-23363. doi: 10.1074/jbc.M709651200

Swiggard, W. J., Baytop, C., Yu, J. J., Dai, J., Li, C., Schretzenmair, R., et al. (2005). Human immunodeficiency virus type 1 can establish latent infection in resting CD4+ T Cells in the absence of activating stimuli. J. Virol. 79, 14179-14188. doi: 10.1128/JVI.79.22.14179-14188.2005

Swiggard, W. J., O'Doherty, U., McGain, D., Jeyakumar, D., and Malim, M. H. (2004). Long HIV Type 1 reverse transcripts can accumulate stably within resting CD4+ $\mathrm{T}$ cells while short ones are degraded. AIDS Res. Hum. Retroviruses 20, 285-295. doi: 10.1089/088922204322996527

Swingler, S., Mann, A. M., Zhou, J., Swingler, C., and Stevenson, M. (2007). Apoptotic killing of HIV-1-infected macrophages is subverted by the viral envelope glycoprotein. PLoS Pathog. 3:e134. doi: 10.1371/journal.ppat.0030134

Symons, J., Chopra, A., Malatinkova, E., de Spiegelaere, W., Leary, S., Cooper, D., et al. (2017). HIV integration sites in latently infected cell lines: evidence of ongoing replication. Retrovirology 14:2. doi: 10.1186/s12977-016-0325-2

Tagarro, A., Chan, M., Zangari, P., Ferns, B., Foster, C., De Rossi, A., et al. (2018). Early and highly suppressive antiretroviral therapy are main factors associated with low viral reservoir in european perinatally HIV-infected children. J. Acquir. Immune Defic. Syndr. 79, 269-276. doi: 10.1097/QAI.0000000000001789

Tapia, G., Højen, J. F., Ökvist, M., Olesen, R., and Leth, S., Nissen, S. K., et al. (2017). Sequential Vacc- $4 \mathrm{x}$ and romidepsin during combination antiretroviral therapy (cART): immune responses to Vacc-4x regions on p24 and changes in HIV reservoirs. J. Infect. 75, 555-571. doi: 10.1016/j.jinf.2017.09.004

Tateishi, H., Monde, K., Anraku, K., Koga, R., Hayashi, Y., Ciftci, H. I., et al. (2017). A clue to unprecedented strategy to HIV eradication: "Lock-in and apoptosis." Sci. Rep. 7:8957. doi: 10.1038/s41598-017-09129-w

Tebas, P., Stein, D., Tang, W. W., Frank, I., Wang, S. Q., Lee, G., et al. (2014). Gene editing of CCR5 in autologous CD4 T cells of persons infected with HIV. N. Engl. J. Med. 370, 901-910. doi: 10.1056/NEJMoa13 00662 
Thibault, S., Imbeault, M., Tardif, M. R., and Tremblay, M. J. (2009). TLR5 stimulation is sufficient to trigger reactivation of latent HIV-1 provirus in $\mathrm{T}$ lymphoid cells and activate virus gene expression in central memory CD4+ T cells. Virology 389, 20-25. doi: 10.1016/j.virol.2009. 04.019

Thomas, J., Ruggiero, A., Procopio, F. A., Pantaleo, G., Paxton, W. A., and Pollakis, G. (2019). Comparative analysis and generation of a robust HIV-1 DNA quantification assay. J. Virol. Methods 263, 24-31. doi: 10.1016/j.jviromet.2018.10.010

Tran, T.-A., de Goër de Herve, M.-G., Hendel-Chavez, H., Dembele, B., Le Névot, E., Abbed, K., et al. (2008). Resting regulatory CD4 T cells: a site of HIV persistence in patients on long-term effective antiretroviral therapy. PLoS ONE 3:e3305. doi: 10.1371/journal.pone.00 03305

Trypsteen, W., Vynck, M., de Neve, J., Bonczkowski, P., Kiselinova, M., Malatinkova, E., et al. (2015). Ddpcrquant: threshold determination for single channel droplet digital PCR experiments. Anal. Bioanal. Chem. 407, 5827-5834. doi: 10.1007/s00216-015-8773-4

Tsai, A., Irrinki, A., Kaur, J., Cihlar, T., Kukolj, G., Sloan, D. D., et al. (2017). Toll-like receptor 7 agonist GS-9620 induces HIV expression and HIV-specific immunity in cells from HIV-infected individuals on suppressive antiretroviral therapy. J. Virol. 91:e02166-16. doi: 10.1128/JVI.02166-16

Ueda, S., Ebina, H., Kanemura, Y., Misawa, N., and Koyanagi, Y. (2016). Anti-HIV-1 potency of the CRISPR/Cas9 system insufficient to fully inhibit viral replication. Microbiol. Immunol. 60, 483-496. doi: 10.1111/1348-0421. 12395

Valverde-Villegas, J. M., Matte, M. C. C., Medeiros, R. M., de, and Chies, J. A. B. (2015). New insights about Treg and Th17 cells in HIV infection and disease progression. J. Immunol. Res. 2015:647916. doi: 10.1155/2015/647916

van der Sluis, R. M., Kumar, N. A., Pascoe, R. D., Zerbato, J. M., Evans, V. A., Dantanarayana, A. I., et al. (2020). Combination immune checkpoint blockade to reverse HIV latency. J. Immunol. 204, 1242-1254. doi: 10.4049/jimmunol.1901191

van der Sluis, R. M., van Montfort, T., Centlivre, M., Schopman, N. C. T., Cornelissen, M., Sanders, R. W., et al. (2013). Quantitation of HIV-1 DNA with a sensitive TaqMan assay that has broad subtype specificity. J. Virol. Methods 187, 94-102. doi: 10.1016/j.jviromet.2012.09.019

Van Zyl, G. U., Katusiime, M. G., Wiegand, A., McManus, W. R., Bale, M. J., Halvas, E. K., et al. (2017). No evidence of HIV replication in children on antiretroviral therapy. J. Clin. Invest. 127, 3827-3834. doi: 10.1172/JCI 94582

Vandergeeten, C., Fromentin, R., Merlini, E., Lawani, M. B., DaFonseca, S., Bakeman, W., et al. (2014). Cross-clade ultrasensitive PCR-based assays to measure HIV persistence in large-cohort studies. J. Virol. 88, 12385-12396. doi: 10.1128/JVI.00609-14

Vatakis, D. N., Bristol, G., Wilkinson, T. A., Chow, S. A., and Zack, J. A. (2007). Immediate activation fails to rescue efficient human immunodeficiency virus replication in quiescent $\mathrm{CD} 4+\mathrm{T}$ Cells. J. Virol. 81, 3574-3582. doi: 10.1128/JVI.02569-06

Vitone, F., Gibellini, D., Schiavone, P., and Re, M. C. (2005). Quantitative DNA proviral detection in HIV-1 patients treated with antiretroviral therapy. J. Clin. Virol. 33, 194-200. doi: 10.1016/j.jcv.2004.11.003

von Stockenstrom, S., Odevall, L., Lee, E., Sinclair, E., Bacchetti, P., Killian, M., et al. (2015). Longitudinal genetic characterization reveals that cell proliferation maintains a persistent HIV Type 1 DNA pool during effective HIV therapy. J. Infect. Dis. 212, 596-607. doi: 10.1093/infdis/jiv092

Wagner, T. A. (2018). Quarter century of anti-HIV CAR T cells. Curr. HIV/AIDS Rep. 15, 147-154. doi: 10.1007/s11904-018-0388-x

Wagner, T. A., McKernan, J. L., Tobin, N. H., Tapia, K. A., Mullins, J. I., and Frenkel, L. M. (2013). An increasing proportion of monotypic HIV1 DNA sequences during antiretroviral treatment suggests proliferation of HIV-infected cells. J. Virol. 87, 1770-1778. doi: 10.1128/JVI.01985-12

Wagner, T. A., McLaughlin, S., Garg, K., Cheung, C. Y. K., Larsen, B. B., Styrchak, S., et al. (2014). Proliferation of cells with HIV integrated into cancer genes contributes to persistent infection. Science 345, 570-573. doi: 10.1126/science. 1256304
Wang, G., Zhao, N., Berkhout, B., and Das, A. T. (2016). CRISPR-Cas9 can inhibit HIV-1 replication but NHEJ repair facilitates virus escape. Mol. Ther. 24, 522-526. doi: 10.1038/mt.2016.24

Wang, Q., Chen, S., Xiao, Q., Liu, Z., Liu, S., Hou, P., et al. (2017). Genome modification of CXCR4 by Staphylococcus aureus Cas9 renders cells resistance to HIV-1 infection. Retrovirology 14:51. doi: 10.1186/s12977-017-0375-0

Wang, Q., Liu, S., Liu, Z., Ke, Z., Li, C., Yu, X., et al. (2018). Genome scale screening identification of SaCas9/gRNAs for targeting HIV-1 provirus and suppression of HIV-1 infection. Virus Res. 250, 21-30. doi: 10.1016/j.virusres.2018.04.002

Wang, W., Ye, C., Liu, J., Zhang, D., Kimata, J. T., and Zhou, P. (2014). CCR5 gene disruption via lentiviral vectors expressing Cas9 and single guided RNA renders cells resistant to HIV-1 infection. PLoS ONE 9:e115987. doi: 10.1371/journal.pone.0115987

Wang, Z., Gurule, E. E., Brennan, T. P., Gerold, J. M., Kwon, K. J., Hosmane, N. N., et al. (2018). Expanded cellular clones carrying replication-competent HIV-1 persist, wax, and wane. Proc. Natl. Acad. Sci. U.S.A. 115, E2575-E2584. doi: 10.1073/pnas.1720665115

Weinberger, A. D., and Weinberger, L. S. (2013). XStochastic fate selection in HIV-infected patients. Cell 155, 497-499. doi: 10.1016/j.cell.2013.09.039

Whitney, J. B., Hill, A. L., Sanisetty, S., Penaloza-Macmaster, P., Liu, J., Shetty, M., et al. (2014). Rapid seeding of the viral reservoir prior to SIV viraemia in rhesus monkeys. Nature 512, 74-77. doi: 10.1038/nature13594

Wilburn, K. M., Mwandumba, H. C., Jambo, K. C., Boliar, S., Solouki, S., Russell, D. G., et al. (2016). Heterogeneous loss of HIV transcription and proviral DNA from 8E5/LAV lymphoblastic leukemia cells revealed by RNA FISH: FLOW analyses. Retrovirology 13:55. doi: 10.1186/s12977-01 6-0289-2

Williams, J. P., Hurst, J., Stöhr, W., Robinson, N., Brown, H., Fisher, M., et al. (2014). HIV-1 DNA predicts disease progression and post-treatment virological control. Elife 3:e03821. doi: 10.7554/eLife.03821

Williams, S. A., Chen, L.-F., Kwon, H., Fenard, D., Bisgrove, D., Verdin, E., et al. (2004). Prostratin antagonizes HIV latency by activating NF-кB. J. Biol. Chem. 279, 42008-42017. doi: 10.1074/jbc.M402124200

Wonderlich, E. R., Subramanian, K., Cox, B., Wiegand, A., Lackman-Smith, C., Bale, M. J., et al. (2019). Effector memory differentiation increases detection of replication-competent HIV-l in resting CD4+ T cells from virally suppressed individuals. PLoS Pathog. 15:e1008074. doi: 10.1371/journal.ppat.1008074

Wong, J. K., Hezareh, M., Günthard, H. F., Havlir, D. V., Ignacio, C. C., Spina, C. A., et al. (1997). Recovery of replication-competent HIV despite prolonged suppression of plasma viremia. Science 278, 1291-1295. doi: $10.1126 /$ science.278.5341.1291

Wong, M. E., Jaworowski, A., and Hearps, A. C. (2019). The HIV reservoir in monocytes and macrophages. Front. Immunol. 10:1435. doi: 10.3389/fimmu.2019.02517

Xiao, Q., Guo, D., and Chen, S. (2019). Application of CRISPR/Cas9-based gene editing in HIV-1/AIDS Therapy. Front. Cell. Infect. Microbiol. 9:69. doi: $10.3389 /$ fcimb. 2019.00069

Xing, S., Bullen, C. K., Shroff, N. S., Shan, L., Yang, H.-C., Manucci, J. L., et al. (2011). Disulfiram reactivates latent HIV-1 in a Bcl-2-transduced primary CD4+ T cell model without inducing global T cell activation. J. Virol. 85, 6060-6064. doi: 10.1128/JVI.02033-10

Xu, L., Yang, H., Gao, Y., Chen, Z., Xie, L., Liu, Y., et al. (2017). CRISPR/Cas9mediated CCR5 ablation in human hematopoietic stem/progenitor cells confers HIV-1 resistance in vivo. Mol. Ther. 25, 1782-1789. doi: 10.1016/j.ymthe.2017.04.027

Yin, C., Zhang, T., Qu, X., Zhang, Y., Putatunda, R., Xiao, X., et al. (2017). In vivo excision of HIV-1 provirus by saCas 9 and multiplex single-guide RNAs in animal models. Mol. Ther. 25, 1168-1186. doi: 10.1016/j.ymthe.2017.03.012

Yu, J. J., Wu, T. L., Liszewski, M. K., Dai, J., Swiggard, W. J., Baytop, C., et al. (2008) A more precise HIV integration assay designed to detect small differences finds lower levels of integrated DNA in HAART treated patients. Virology 379, 78-86. doi: 10.1016/j.virol.2008.05.030

Yucha, R. W., Hobbs, K. S., Hanhauser, E., Hogan, L. E., Nieves, W., Ozen, M. O., et al. (2017). High-throughput characterization of HIV-1 reservoir reactivation using a single-cell-in-droplet PCR assay. EBiomedicine 20, 217-229. doi: 10.1016/j.ebiom.2017.05.006 
Yukl, S. A., Gianella, S., Sinclair, E., Epling, L., Li, Q., Duan, L., et al. (2010). Differences in HIV burden and immune activation within the gut of HIVpositive patients receiving suppressive antiretroviral therapy. J. Infect. Dis. 202, 1553-1561. doi: 10.1086/656722

Yukl, S. A., Kaiser, P., Kim, P., Telwatte, S., Joshi, S. K., Vu, M., et al. (2018). HIV latency in isolated patient CD4+ T cells may be due to blocks in HIV transcriptional elongation, completion, and splicing. Sci. Transl. Med. 10:eaap9927. doi: 10.1126/scitranslmed.aap9927

Zaikos, T. D., Painter, M. M., Sebastian Kettinger, N. T., Terry, V. H., and Collins, K. L. (2018). Class 1-selective histone deacetylase (HDAC) inhibitors enhance HIV latency reversal while preserving the activity of HDAC isoforms necessary for maximal HIV gene expression. J. Virol. 92:e2110-e02117. doi: 10.1128/JVI.02110-17
Conflict of Interest: The authors declare that the research was conducted in the absence of any commercial or financial relationships that could be construed as a potential conflict of interest.

The handling editor declared a past co-authorship with one of the authors GP.

Copyright $\odot 2020$ Thomas, Ruggiero, Paxton and Pollakis. This is an open-access article distributed under the terms of the Creative Commons Attribution License (CC $B Y)$. The use, distribution or reproduction in other forums is permitted, provided the original author(s) and the copyright owner(s) are credited and that the original publication in this journal is cited, in accordance with accepted academic practice. No use, distribution or reproduction is permitted which does not comply with these terms. 